\title{
A review of amphibian fauna of Sri Lanka: distribution, recent taxonomic changes and conservation
}

\author{
Sudesh Batuwita $^{1^{*}}$, Sampath Udugampala ${ }^{2 *}$, Madura De Silva ${ }^{2}$, Jiaojiao Diao ${ }^{3}$ and Udeni \\ Edirisinghe $^{4}$
}

${ }^{I}$ The Society for the Biodiversity Conservation, 63/4, Adikaramwatta, Yaggahapitiya, Gunnepana 20270, Kandy, Sri Lanka

${ }^{2}$ Wildlife Conservation Society- Galle, Hiyare reservoir, Hiyare 80056, Galle, Sri Lanka

${ }^{3}$ College of Biology and Environment, Nanjing Forestry University, 159 Longpan Road, Nanjing, China

${ }^{4}$ Postgraduate Institute of Agriculture, University of Peradeniya, Peradeniya 20400, Sri Lanka

*These authors contributed equally to this work

Corresponding author $\bowtie$ : sudesh.batuwita@gmail.com

Received: 25 November 2019 Accepted: 24 December 2019 Published online: 31 December 2019

\begin{abstract}
The amphibian fauna of Sri Lanka comprises 120 species, including 107 $(\sim 90.0 \%)$ endemic species. They belong to five families: Bufonidae, Dicroglossidae, Ichthyophiidae, Microhylidae, and Rhacophoridae. Based on distribution, we recognized five zoogeographic zones for them, Central Hills, Dry Zone, Knuckles Range, Lowland Wet Zone, and Rakwana Hills. Fifty three species were reported from the Central Hills (48 endemics [90.6\%] and 42 [79.2\%] threatened species). 47 species were recorded from the Lowland Wet Zone, including 36 (76.6\%) endemics and $28(59.6 \%)$ threatened species. The Knuckles Range had 25 species, of which, 19 (76.0\%) were endemics and $15(60.0 \%)$ are threatened species. 19 species were reported from Dry Zone including seven endemics (36.8\%) and four threatened species (21.1\%). Out of 29 species, which inhabited in the Rakwana Hills, 26 were endemics $(\sim 89.7 \%)$ including $24(82.8 \%)$ threatened species. Species diversity along the elevational gradient was also observed with the highest species richness in the mid-elevational localities. Family Ichthyophiidae can be considered as the least studied family. Recent rediscoveries and studies have helped to reduce the number of extinct species from 21 to 18 . It is speculated that some of the other extinct species have to be rediscovered or probably were misidentified as other species. About $90 \%$ of Sri Lankan amphibians occur in the regions with the highest human populations where there are established agricultural lands. Loss of habitats, competition due to anthropogenic species and invasive species, pollution (cause for malformations, parasites, and other diseases), and climate change appear to be major threats.
\end{abstract}

Key words: Climate change, conservation, endemic, extinct, threatened, Sri Lanka

\section{Introduction}

Sri Lanka is a continental island in the south region of Asia with a high rate of biodiversity. Sri Lanka is also considered a reservoir of unique evolutionary history (Myers et al., 2000; 
Bossuyt et al., 2004). In addition, Sri Lanka is known as a biodiversity hotspot in the revised hotspots of the world along with the Western Ghats of India (Mittermeier et al., 1998). Moreover, recently, the Central Highland of Sri Lanka (Horton Plains, Knuckles Range, and Peak Wilderness) was declared as a World Heritage Site (UNESCO, 2010). Apart from that, a southwestern quarter of Sri Lanka is known as a unique conservation region (Gunatilleke et al., 2005). Gunatilleke et al. (2005) described a model river basin landscape-seascape conservation area for the southwestern hill forests of Sri Lanka along the Gin River. An assessment of forest resources in Sri Lanka in 1992 indicated that the total forest cover (including forest plantations) is about $32.2 \%$ of its total land area ( 6.7 million ha), while the percentage of closed-canopy natural forest areas was $23.9 \%$, sparse and open forests was about $7.0 \%$ and the area of the forest plantations was about $1.3 \%$ of total land area (Legg and Jewell, 1995).

Within this high biodiversity, amphibians can be considered as one of the best-studied groups among the other vertebrates (Manamendra-Arachchi and Pethiyagoda, 2006; Frost, 2018; Meegaskumbura et al, 2019). In the 18th century, based on Seba's drawing (Seba, 1735), the first amphibian species from Sri Lanka, 'Serpens caecilia ceylonica', synonym of Ichthyophis glutinosus (Linnaeus, 1758) was described. Subsequently, in the 19th century contributions are noticeable. Kelaart (1854) described a detailed summary of amphibians of Sri Lanka, which included 10 species. Following Kelaart (1854), several authors reported or described amphibians from Sri Lanka and species number peaked between mid-19th and mid-20th century owing to the works of following authors: Lichtenstein and Martens (1856), Günther (1858; 1859; 1864; 1869; 1872; 1876a, b), Boulenger (1882a, b; 1904; 1905), Méhely (1897), Ahl (1927), Parker (1934), Parker and Osman Hill (1948), and Shreve (1940).

Following this period, Kiritisinghe (1957) published his classic book on Sri Lankan amphibians, 'The Amphibia of Ceylon'. However, within the Sri Lankan amphibian assemblage, Kirtisinghe (1957) recognized a lesser number of Pseudophilautus Laurent, 1943 (as Philautus Gistel, 1848 or Rhacophorus Kuhl and van Hasselt, 1822 or as Theloderma Tschudi, 1838) species and synonymised many rhacophorid species that reduced the number of species from 34 to 8. Dutta and Manamendra-Arachchi (1996) elevated the number of rhacophorids to 17, and then Manamendra-Arachchi and Pethiyagoda (2001b; 2005), and Meegaskumbura and Manamendra-Arachchi (2005) increased it to 65, which includes 60 Pseudophilautus (excluding the Pseudophilautus semiruber (Annandale, 1913)). Manamendra-Arachchi and Pethiyagoda (2005) considered this species as a Data Deficient taxon. In addition, subsequent new species descriptions raised the Pseudophilautus species assemblage up to 77 (Meegaskumbura and Manamendra-Arachchi, 2011; Meegaskumbura et al., 2007; 2009; 2012a; Wickramasinghe et al., 2013a; 2015; Batuwita et al., 2019b). In addition to Pseudophilautus species, several new species were also added to the Sri Lankan amphibian assemblage as well (Fernando et al., 1994; Fernando and Siriwardhane, 1996; Manamendra-Arachchi and Gabadage, 1996; Manamendra-Arachchi and Pethiyagoda, 1998; 2001a, b; Fernando et al., 2007; Wickramasinghe et al., 2012a; Wijayathilaka et al., 2015; Senevirathne et al., 2018). Also, Kotagama et al. (1981) and De Silva (1995; 1996) published species checklists.

Currently, the amphibian fauna of Sri Lanka consists of five families: Bufonidae Gray, Dicroglossidae Anderson, Ichthyophiidae Taylor, Microhylidae Günther, and Rhacophoridae Hoffman (Frost, 2006). Sri Lanka is also known as a country with amphibian 'megadiversity' with about 250 species (Pethiyagoda and Manamendra-Arachchi, 1998), but to date, this number should revise to 120 (Dutta, 1997; Manamendra-Arachchi and Pethiyagoda, 2006; Fernando et al., 2007; Biju et al., 2014; Jayawardena et al., 2017; Meegaskumbura et al., 2015; Frost, 2018; Senevirathne et al., 2018; Batuwita et al., 2019b). This is only second to 
Costa Rica (Table 1), due to the highest density of species per unit area $(\sim 1.8$ species per 1000

$\mathrm{km}^{2}$ ). Even though Sri Lanka has a higher amphibian species diversity, threats to the species of amphibians are increasing at an alarming rate. According to the IUCN Red List of Threatened Species (IUCN, 2007), the threatened amphibian species were $52(49.1 \%)$ in 2007 (Table 2). However, the recent report (IUCN, 2012) confirmed that the number of threatened species rapidly increased to $72(64.9 \%)$. Based on this data, Sri Lankan amphibians are considered as one of the major threatened vertebrate species (see also Bopage et al., 2011; Manamendra-Arachchi and Pethiyagoda, 2006; De Silva and Wijayathilaka, 2019).

Thus, the purpose of this review is to evaluate the amphibian fauna of Sri Lanka by discussing their distribution, recent taxonomic changes, threats, and conservation.

Table 1: Species diversity of amphibians in selected 'megadiversity' countries of the world (Modified after Pethiyagoda and Manamendra-Arachchi, 1998).

\begin{tabular}{lcc}
\hline Country & Total No. of amphibian species & Species density $\left.\mathbf{( 1 0 0 0} \mathbf{~ k m}^{\mathbf{}}\right)$ \\
\hline China & 389 & 0.04 \\
Brazil & 516 & 0.06 \\
Zaire & 216 & 0.09 \\
India & 384 & 0.12 \\
Indonesia & 270 & 0.13 \\
Venezuela & 197 & 0.22 \\
Colombia & 407 & 0.36 \\
Ecuador & 358 & 1.30 \\
Sri Lanka & 120 & 1.83 \\
Costa Rica & 140 & 2.75 \\
\hline
\end{tabular}

Table 2: Species richness and endemism among Sri Lankan amphibians (National Red list; IUCN, 2007).

\begin{tabular}{lcc}
\hline & Number of species & Number of endemic species \\
\hline Total species & 106 & 90 \\
Critically endangered & 12 & 12 \\
Endangered & 34 & 34 \\
Vulnerable & 6 & 5 \\
Total threatened & 52 & 51 \\
\hline
\end{tabular}

\section{Material and Methods}

All extant species were allocated to five different separable groups (Fig. 1) according to their distribution, viz., (1) the Lowland Wet Zone confined to the southwestern quarter of the island (mean annual precipitation $>2000 \mathrm{~mm}$ ), which extends from sea coast to the interior (from a.s.l. [0 m] up to about $1000 \mathrm{~m}$ a.s.l.) including the Haycock Mountain $(\sim 660 \mathrm{~m})$, the Sinharaja World Heritage Site (WHS) ( $600 \mathrm{~m})$ and excluding the Central Hills, the Knuckles Range, and the eastern Sinharaja; (2) the Central Hills: from $500 \mathrm{~m}$ to its highest peak at Pidurutalagala ( $2524 \mathrm{~m}$ ) including the Peak Wilderness; (3) the Knuckles Range: from 500 $\mathrm{m}$ to about $1863 \mathrm{~m}$ (the highest peak) elevation; (4) the Dry Zone: from coast to interior from a.s.l. (0 m) to $500 \mathrm{~m}$ (mean annual precipitation <2000 m); and (5) the Rakwana Hills: 
including Gongala (Hayes) and Handapana Ella Plains (from $1000 \mathrm{~m}$ to its highest elevation, $\sim 1358 \mathrm{~m}$ ).

The distribution of species are based on the data gathered from previously published literature: monographs (Dutta and Manamendra-Arachchi, 1996; Manamendra-Arachchi and Pethiyagoda, 2006), periodicals (Fernando et al., 2007; Wickramasinghe et al., 2012a, b; Wickramasinghe et al., 2013b; 2015; Batuwita et al., 2019b), reports, IUCN (1999; 2007; 2012), WCSG (2008; 2009), together with personal observations based on field observations by the first three authors during 1997 to 2014. Elevations were classified as follows: (1) Low elevations (<800 m), (2) Mid-elevations ( $~ 800 \mathrm{~m}$ to $\sim 1700 \mathrm{~m})$, and (3) High elevations (1700 $\mathrm{m}$ to $2500 \mathrm{~m})$.

For the distribution study, all putative extinct species were excluded. Photographs were taken by Cannon IXUS50 and Nikon D700 digital cameras. Elevations are given in metres (m) from mean sea level. Map with zoogeographic zones was prepared by using the ARC GIS 10.1 software.

For higher-level taxonomy, we followed Frost et al. (2006) and in species taxonomy the following literature were used: Frost et al. (2006), Manamendra-Arachchi and Pethiyagoda (2006), Fernando et al. (2007), Joshy et al. (2009), Li et al. (2013), Biju et al. (2014), Khajeh et al. (2014), Meegaskumbura et al. (2015), Oliver et al. (2015), Peloso et al. (2016), Wijayathilaka et al. (2016), Garg et al. (2018), Sanchez et al. (2018), Batuwita et al. (2019b), and Chandramouli et al. (2019). The conservation statuses of species were taken from the following published sources: Fernando et al. (2007); IUCN (1999; 2007; 2012); ManamendraArachchi and Pethiyagoda (2006); Wickramasinghe et al. (2013b; 2015); and Batuwita et al. (2019b). Recent taxonomic changes to the species were discussed after ManamendraArachchi and Pethiyagoda (2006).

Abbreviations used: BMNH, British Museum Natural History (Natural History Museum, London [NHM]); WCSG, Wildlife Conservation Society-Galle of Sri Lanka; WHT, Wildlife Heritage Trust of Sri Lanka; a.s.l., above sea level.

\section{Results}

\section{Endemic and threatened amphibians}

Sri Lanka has 120 amphibian species (Appendix 1; Table 3), of which 107 ( 90.0\%) are endemics and more than $80 \%$ are restricted to rain forests (Manamendra-Arachchi and Pethiyagoda, 2006; Fernando et al., 2007; Meegaskumbura et al., 2009; Meegaskumbura and Manamendra-Arachchi, 2011; Wickramasinghe et al., 2012a, b; Wickramasinghe et al., 2013a; 2015; Batuwita et al., 2019b). Eighteen endemic species of amphibians are currently confirmed as extinct (Manamendra-Arachchi and Pethiyagoda, 2005; 2006; Meegaskumbura et al., 2007; 2012a; 2015; Wickramasinghe et al., 2012b; 2013b, c), which includes a single species from a relic genus, Nannophrys Günther, 1869 and 17 species from Pseudophilautus. Thus, once the extinct species are excluded, the total number of amphibian species are 102 (including 89 endemics). All species of the family Rhacophoridae (with the exception of Polypedates maculatus (Gray, 1834)) and three species that belong to the family Ichthyophiidae are endemic to Sri Lanka (Fig. 2A, B). Family Microhylidae contains $70 \%$ of the endemic species. As a percentage, Bufonidae and Dicroglossidae are showing more or less similar figures (Fig. 2B). Out of seven species reported from the family Bufonidae, four taxa are endemics. Seventeen species of Dicroglossidae were recorded including 10 endemics (Fig. 2A). 
The endemic genera in Sri Lanka are: Adenomus Cope, 1861, Lankanectes Dubois and Ohler, 2001, Nannophrys, and Taruga Meegaskumbura, Meegaskumbura, Bowatte, ManamendraArachchi, Pethiyagoda, Hanken and Schneider, 2010. Species of the endemic genera are confined to all zoogeographic zones, but in the Dry Zone, they are restricted to the highest elevations only (i.e., isolated hills with humid forests). When considering the threatened species, except families Dicroglossidae and Microhylidae, all the other families contained a higher percentage ( 60\%) of threatened species (Fig. 2B).

Table 3: Putative extinct amphibian species of Sri Lanka.

\begin{tabular}{|c|c|c|}
\hline Family & Species & Type locality \\
\hline Dicroglossidae & Nannophrys guentheri Boulenger, 1882 & 'Ceylon' \\
\hline \multirow{17}{*}{ Rhacophoridae } & Pseudophilautus adspersus (Günther, 1872) & Nuwara Eliya \\
\hline & Pseudophilautus dimbullae (Shreve, 1940) & $\begin{array}{l}\text { Queenwood Est., Dimbullen } \\
\text { (= Dimbulla), 'Ceylon' }\end{array}$ \\
\hline & Pseudophilautus eximius (Shreve, 1940) & $\begin{array}{l}\text { Queenwood Est., Dimbullen } \\
\text { (= Dimbulla), 'Ceylon' }\end{array}$ \\
\hline & $\begin{array}{l}\text { Pseudophilautus extirpo (Manamendra-Arachchi and } \\
\text { Pethiyagoda, 2005) }\end{array}$ & 'Ceylon' \\
\hline & Pseudophilautus halyi (Boulenger, 1904) & Pattipola \\
\hline & $\begin{array}{l}\text { Pseudophilautus leucorhinus (Lichtenstein and } \\
\text { Martens, 1856) }\end{array}$ & 'Ceylon’ \\
\hline & $\begin{array}{l}\text { Pseudophilautus maia (Meegaskumbura, } \\
\text { Manamendra-Arachchi, Schneider and Pethiyagoda, } \\
\text { 2007) }\end{array}$ & $\begin{array}{l}\text { "Poojagodde" [Poojagoda] } \\
\text { Estate, Ramboda, Sri Lanka }\end{array}$ \\
\hline & Pseudophilautus malcolmsmithi (Ahl, 1927) & 'Ceylon' \\
\hline & Pseudophilautus nanus (Günther, 1869) & 'Ceylon' \\
\hline & Pseudophilautus nasutus (Günther, 1869) & 'Ceylon’ \\
\hline & Pseudophilautus oxyrhynchus (Günther, 1872) & 'Ceylon’ \\
\hline & $\begin{array}{l}\text { Pseudophilautus pardus (Meegaskumbura, } \\
\text { Manamendra-Arachchi, Schneider and Pethiyagoda, } \\
\text { 2007) }\end{array}$ & ‘Ceylon’ \\
\hline & Pseudophilautus rugatus (Ahl, 1927) & 'Taralanda' or 'Farnlands' \\
\hline & Pseudophilautus temporalis (Günther, 1864) & 'Ceylon’ \\
\hline & Pseudophilautus variabilis (Günther,1859) & 'Ceylon' \\
\hline & $\begin{array}{l}\text { Pseudophilautus zal (Manamendra-Arachchi and } \\
\text { Pethiyagoda, 2005) }\end{array}$ & 'Ceylon’ \\
\hline & Pseudophilautus zimmeri (Ahl, 1927) & 'Point de Galle, Ceylon' \\
\hline
\end{tabular}

Even though Sri Lanka possesses diverse ecosystems throughout its terrain, endemic amphibians are mostly restricted to the Central Hills, Knuckles Range, Lowland Wet Zone and Rakwana Hills (mean annual precipitation $>2000 \mathrm{~mm}$ ). Senanayake et al. (1977) stated that southern rain forests and montane forests contain a rich assemblage of endemic animals (i.e., excluding the Dry Zone). The above authors view on the endemic fauna is the same as the present findings. Endemic and threatened species that are reported from different zoogeographic zones of Sri Lanka are discussed below. 


\section{Zoogeographic zones and amphibians}

Five different zoogeographic zones for Sri Lankan amphibians were recognized based on their zoogeography (Fig. 1; Appendix 1).

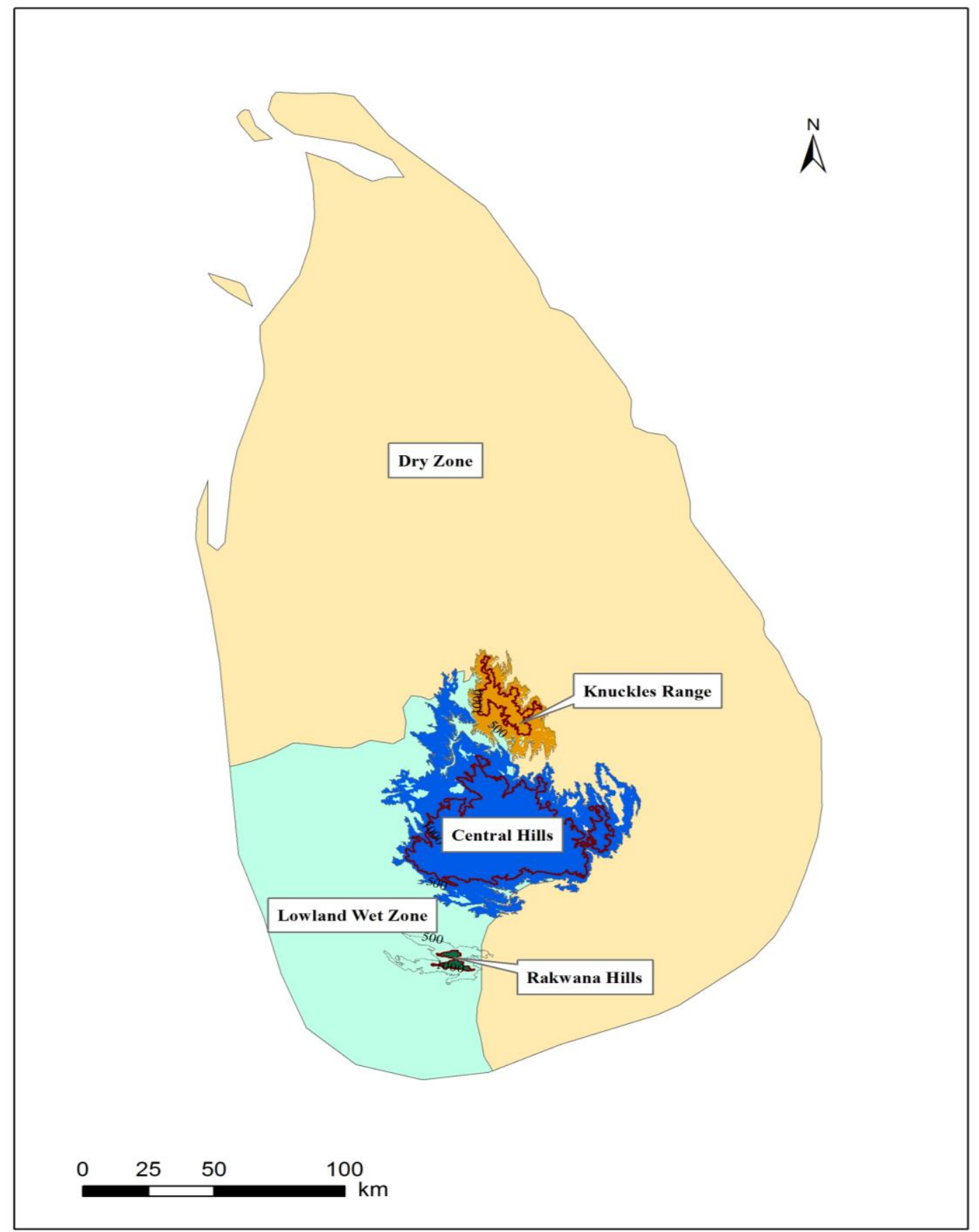

Figure 1: Map showing zoogeographic zones for amphibian fauna of Sri Lanka (Central Hills in blue; Dry Zone in light yellow; Knuckles Range in brown; Lowland Wet Zone in light blue; and Rakwana Hills in dark green; and 1000 m contour line in maroon color).

The Central Hills zoogeographic zone is starting from $500 \mathrm{~m}$ elevation and located within the central region of the island (Fig. 1). Several major forest reserves (e.g., Ambagamuwa, Namunukula, and Pedro; the highest peak 2524 m), sanctuary (e.g., Peak Wilderness), a Strict Nature reserve (e.g., Hakgala) and National Park (e.g., Horton Plains) are included in this zone. Major vegetation types includes: hill rainforest, montane forests, montane grasslands 
(wet patanas) and moist semi-evergreen (intermediate) forests (Ashton et al., 1997). Fifty three species were recorded from this region. This is more than one third of the total extant amphibian fauna of Sri Lanka, and includes 48 endemics $(90.6 \%)$ of which $42(79.2 \%)$ are threatened species. Out of 53 species recorded from the Central Hills, more than half of the species (34 species, 64.2\%) belong to the family Rhacophoridae. Apart from these species, 19 species of amphibians are from other families that were reported from the Central Hills. Therefore, the Central Hills has the highest number of amphibian species as well as threatened amphibians (Fig. 3A).

A

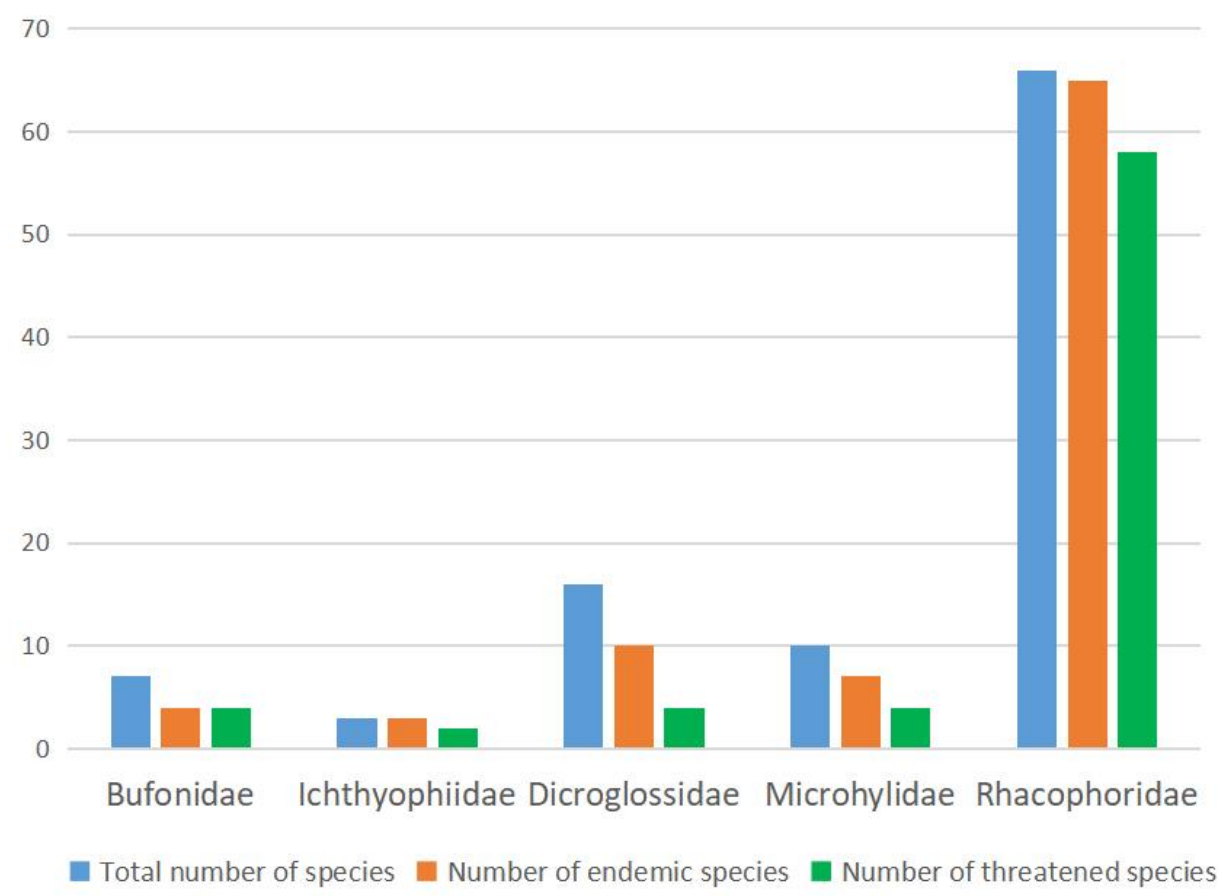

B

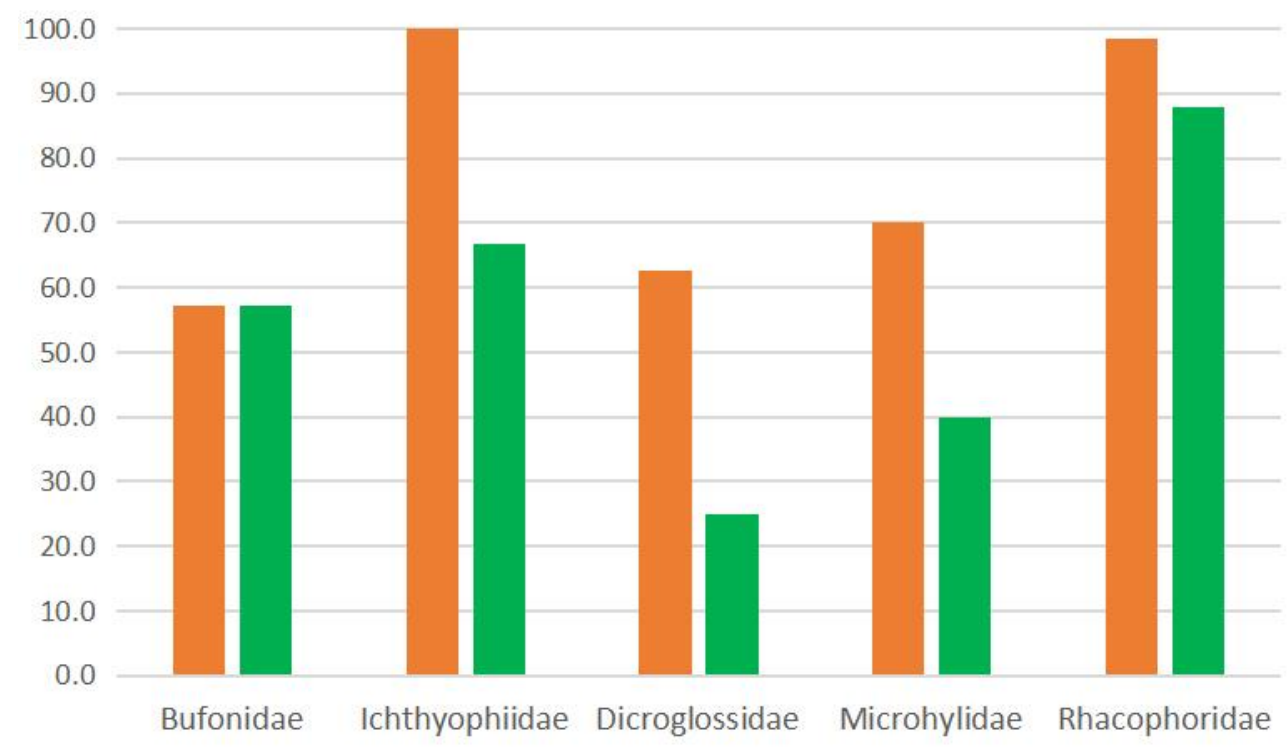

$\%$ of endemic species

$\%$ of threatened species

Figure 2: Amphibian fauna of Sri Lanka: species diversity, endemism and threatened species (A); endemic and threatened species percentages (B). 
The Lowland Wet Zone (Fig. 1) consists of rain forests (below $300 \mathrm{~m}$ a.s.1.) and hill rain forests (300-1000 $\mathrm{m}$ a.s.l. [up to $500 \mathrm{~m}$ ]) as major forest types, which are evergreen forests without significant seasonal changes (Ashton et al., 1997), e.g., Kanneliya-DediyagalaNakiyadeniya Forest Reserves (known as KDN complex), Haycock and Sinharaja WHS. The latter two forests are hill rain forests. This zone receives an annual rainfall of about 2000 $3000 \mathrm{~mm}$. Forty seven species of amphibians were recorded from the Lowland Wet Zone, of which $36(76.6 \%)$ are endemic to Sri Lanka (Fig. 3A, B). The threatened species percentage reported from this area is more or less the same $(\sim 60.0 \%)$ as the threatened species in the Knuckles Range (Fig. 3B).

The Knuckles Range is very recently recognized as a zoogeographic zone (Fig. 1) in Sri Lanka (Pethiyagoda and Manamendra-Arachchi, 1998), which lies within the mid-elevational zone (> 500 m). Major forest types observed in this zone belong to hill rainforest, montane forests, montane grasslands (wet patanas) and moist semi-evergreen (intermediate) forests (Ashton et al., 1997). Twenty five species were recorded from the Knuckles Range, of which $19(76.0 \%)$ are endemic to Sri Lanka and $15(60.0 \%)$ are considered as threatened species (Fig. 3A, B). It has been proven that this is yet another unique zone not only for amphibians e.g., Nannophrys marmorata Kirtisinghe, 1946, three species of Pseudophilautus, viz., P. mooreorum (Meegaskumbura and Manmendra-Arachchi, 2005), P. steineri (Meegaskumbura and Manmendra-Arachchi, 2005), and P. stuarti (Meegaskumbura and ManamendraArachchi, 2005), but also for restricted reptile species as well (Batuwita and Udugampala, 2017).

The Dry Zone (Fig. 1) is the largest zoogeographic zone, which has dry mixed evergreen forests (monsoonal); savannas and thorn scrub major vegetation types (Ashton et al., 1997). However, it has the lowest number of amphibian species, i.e., 19, of which only seven species (36.8\%) are endemic to Sri Lanka. Out of the 19 amphibian species, four are considered as threatened species (Fig. 3A, B). When compared with the other zones, the endemic amphibian diversity in the Dry Zone was very low (Fig. 3A), but two endemic amphibians each from the family Dicroglossidae, Nannophrys naeyakai Fernando, Wickramasinghe, and Rodrigo, 2007 and Rhacophoridae, Pseudophilautus regius (Manamendra-Arachchi and Pethiyagoda, 2005), are confined to the Dry Zone. Many isolated unexplored hilly areas are scattered in this larger zoogeographic zone, e.g., Dolukanda, Gowindahela, Kataragama, Moneragala, Nilgala, Nuwaragala, Rathugala, Ritigala, and Sandagala. Recording vertebrate fauna from these unique areas is difficult, but productive (Bahir and Silva, 2005; Fernando et al., 2007; Wickramasinghe and Munindradasa, 2007; Batuwita et al., 2019a; Karunrathna et al., 2019a, b). Interestingly, a few widely distributed Pseudophilautus species were reported from the above mentioned isolated mountains (Manamendra-Arachchi and Pethiyagoda, 2005; Karunarathna et al., 2008). It is suggested that further studies are needed to evaluate these isolated populations, because unique new species of herpetofauna were described from these hills (Fernando et al., 2007; Wickramasinghe and Munindradasa, 2007; Batuwita et al., 2019a; Karunarathne et al., 2019a, b).

The eastern Sinharaja, Gongala (Hayes) and Hadapana Ella Plains are classified as the Rakwana Hills (Fig. 1), which is a separate zone. Major vegetation types found in this zone belong to submontane forests and submontane grasslands (wet patanas) (Ashton et al., 1997). Within the past two decades, 11 new species of amphibians were discovered from this unique zoogeographic zone (Fernando and Siriwardana, 1996; Manamendra-Arachchi and Pethiyagoda, 2001b; 2005; Meegaskumbura and Manamendra-Arachchi, 2005). A total of 29 species were recorded from the Rakwana Hills (Fig. 3A), which accounted for the highest percentage of threatened species $(82.8 \%)$ and the second largest number of endemic species percentage, $89.7 \%$ (Fig. 3B). Some species inhabiting the Rakwana Hills are considered as 
point endemics, e.g., Taruga fastigo (Manamendra-Arachchi and Pethiyagoda, 2001b) (Fig. 4), and several Pseudophilautus species, including: P. ocularis (Manamendra-Arachchi and Pethiyagoda, 2005), P. lunatus (Manamendra-Arachchi and Pethiyagoda, 2005), P. papillosus (Manamendra-Arachchi and Pethiyagoda, 2005), P. decoris (Manamendra-Arachchi and Pethiyagoda, 2005), and P. procax (Manamendra-Arachchi and Pethiyagoda, 2005).

A
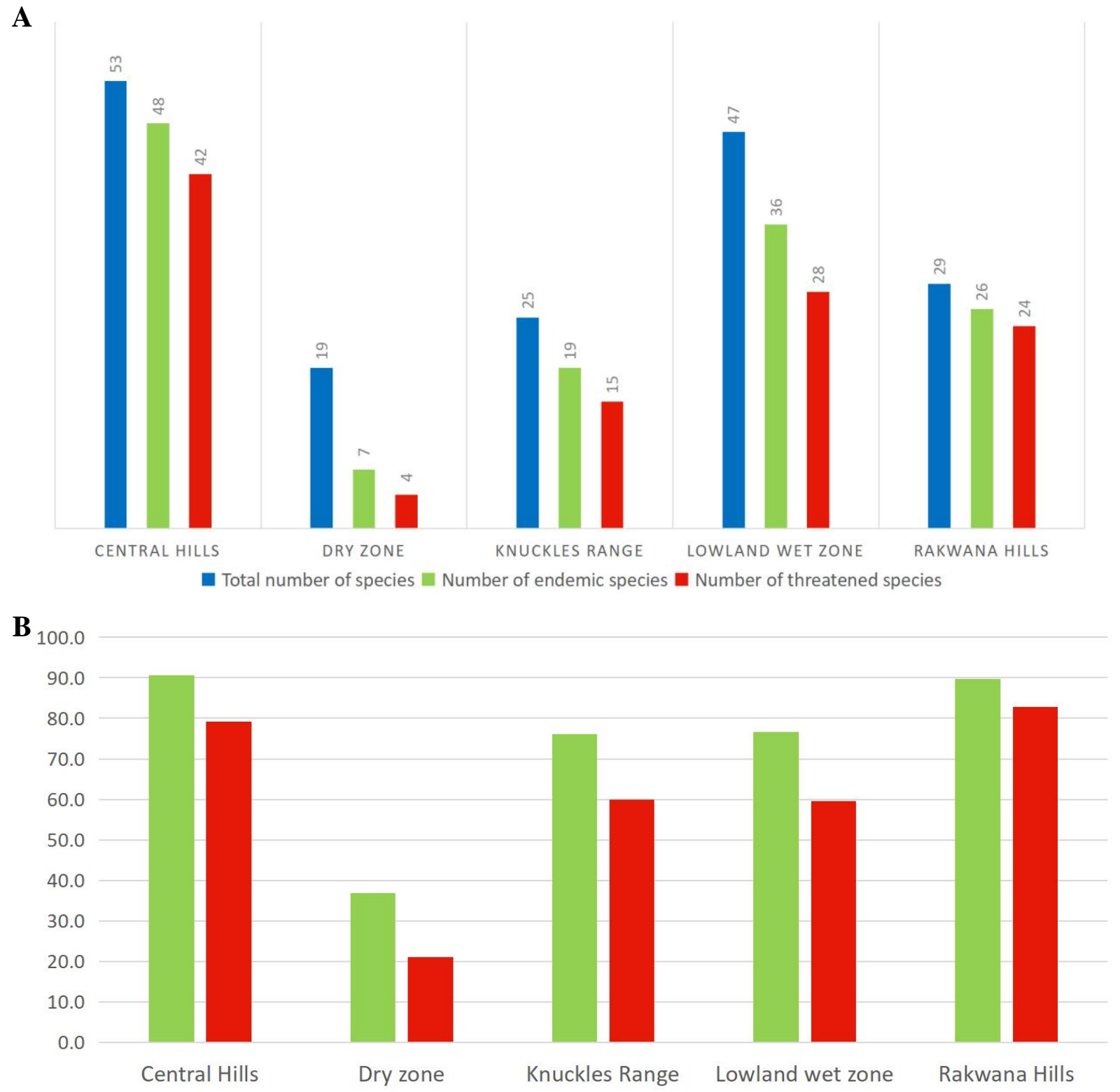

$\%$ of endemic species

$\%$ of threatened species

Figure 3: Species compositions in the different zoogeographic zones including endemic and threatened species (A); percent of endemic, and threatened species in different zone geographic zones, respectively (B).

Apart from the above zoogeographic zones, certain localities with high amphibian richness can be considered as ecotones, e.g., Lowland Wet Zone-Central Hills (Peabotuwage et al., 2012) and Lowland Wet Zone-Rakwana Hills (Janzen and Bopage, 2011). Gosz (1993) and 
Risser (1995) showed that transitional areas share the two types of environments of the habitats that coincide in the ecotone and also have a unique ecotonal environment. Ecotones often support a unique community with additional characteristics to those of the communities adjoining it (Odum, 1953). Recent studies revealed that species inhabiting ecotones have the highest genetic and morphological diversity and also these species have rare and unique alleles (Kark and van Rensburg, 2006). In addition, ecotones are also known as centers of evolutionary novelty, where parapatric (or sympatric) speciation processes may take place (Schilthuizen, 2000).

\section{Species diversity along elevation gradient}

The species distribution according to the elevational gradient for Sri Lankan amphibians were observed (Fig. 5). Elevation ranges starting from a.s.1. $(0 \mathrm{~m})$ to $500 \mathrm{~m}$ and from $500 \mathrm{~m}$ to $1300 \mathrm{~m}$ represented the higher number of species (Fig. 5). These elevations lie within the Central Hills, Knuckles Range, Lowland Wet Zone and Rakwana Hills (Fig. 1). Naniwadekar and Vasudevan (2007) conducted a study in the Western Ghats of Southern India and reported about 12 species as the highest amphibian species richness around $1200 \mathrm{~m}$ elevation. In contrast, present data revealed about 20 species inhabiting more or less similar elevations (from $900 \mathrm{~m}$ to $1200 \mathrm{~m}$ ) and the highest species richness ( 37) were recorded from a.s.l. (0 m) to $700 \mathrm{~m}$ (Fig. 5). Hu et al. (2012) also showed that the distribution of amphibians has great variation according to the differences in the elevations of the respective habitats.

Two species from the family Bufonidae exhibited wide distribution ranges: i.e., Adenomus kelaartii (Günther, 1858) and Duttaphrynus melanostictus (Schneider, 1799). However, the former was not found in the Dry Zone. Adenomus kandianus (Günther, 1872) is restricted to the highest elevational areas (1500-2300 m), whereas Duttaphrynus noellerti (ManamendraArachchi and Pethiyagoda, 1998) is distributed from $200 \mathrm{~m}$ to $500 \mathrm{~m}$ in the Lowland Wet Zone. All but Ichthyophis orthoplicatus Taylor, 1965 are confined to the low and midelevations (60 $\mathrm{m}$ to $1500 \mathrm{~m})$.

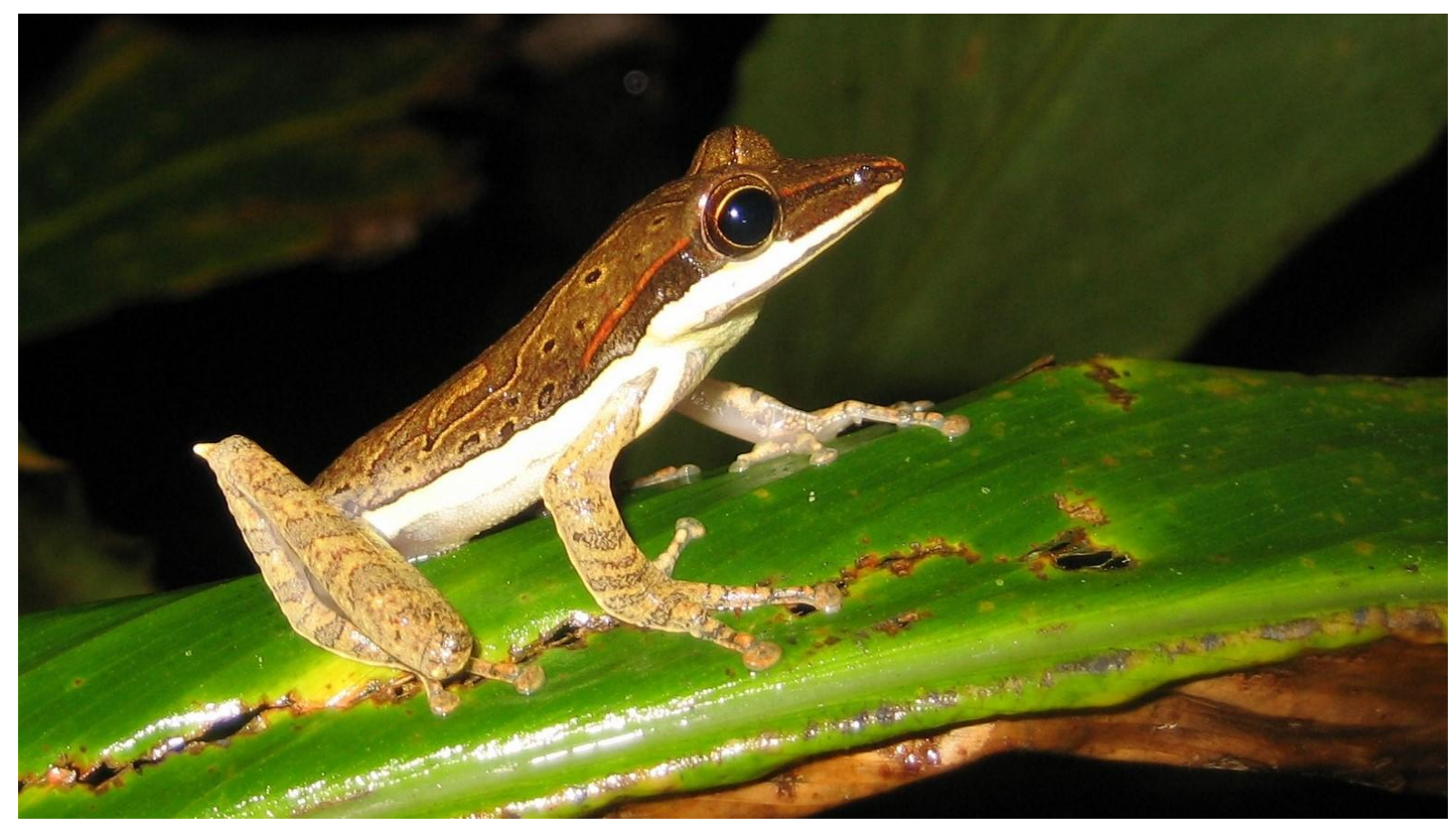

Figure 4: Taruga fastigo, male, from the Morningside Forest Reserve, Rakwana Hills. Photo by Sudesh Batuwita. 


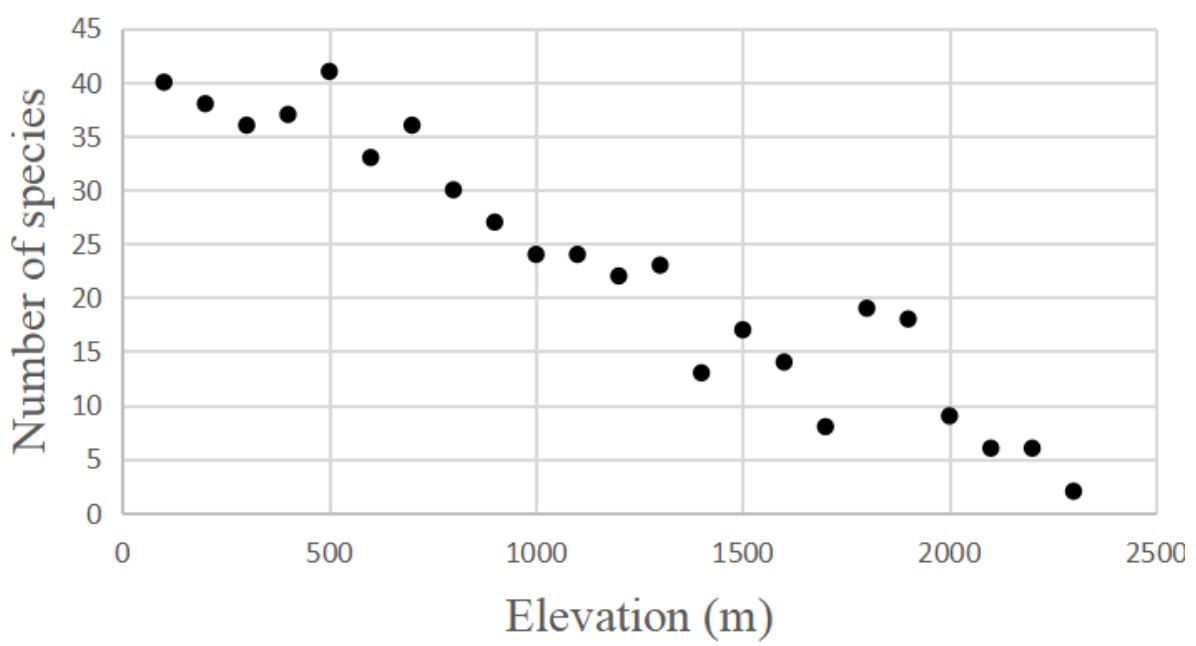

Figure 5: Number of species in different elevations (100 meter intervals).

Microhyla karunaratnei Fernando and Siriwardhane, 1996 and Uperodon obscurus (Günther, 1864) are confined to the low and mid-elevational areas (500 $\mathrm{m}$ to $1200 \mathrm{~m}$ ), whereas Microhyla zeylanica Parker and Osman Hill, 1948 and Uperodon palmatus (Parker, 1934) are found only in high elevational regions. All other species from Microhyliidae were reported from elevations from the coast to up to $500 \mathrm{~m}$ elevation.

Most of the species from the family Dicroglossidae were distributed within the low elevation range (e.g., Hoplobatrachus crassus (Jerdon, 1853), Nannophrys ceylonensis Günther, 1868, Hydrophylax gracilis (Gravenhorst, 1829), Indosylvirana serendipi (Biju, Garg, Mahony, Wijayathilaka, Senevirathne and Meegaskumbura, 2014), Sphaerotheca rolandae (Dubois, 1983)), two species were confined to low and mid-elevation areas between 500-1500 m, Nannophrys marmorata and Lankanectes pera Senevirathne, Samarawickrama, Wijayathilaka, Manamendra-Arachchi, Bowatte, Samarawickrama and Meegaskumbura, 2018, while a single species was confined to elevations ranging from 1500-2500 m within the mid and high elevation areas, viz., Minervarya greenii (Boulenger, 1905). Another five species inhabited wide elevational ranges, sc., Euphlyctis mudigere Joshy, Alam, Kurabayashi, Sumida and Kuramoto, 2009, Indosylvirana temporalis (Günther, 1864), Lankanectes corrugatus (Peters, 1863), Minervarya kirtisinghei (Manamendra-Arachchi and Gabadage, 1996), M. agricola (Jerdon, 1953), and Nannophrys naeyakai. In addition, two species, Euphlyctis hexadactylus (Lesson, 1834) and Sphaerotheca breviceps (Schneider, 1799) were distributed at low elevations 0-760 $\mathrm{m}$ and 0-200 $\mathrm{m}$, respectively.

However, the distribution of the species of Rhacophoridae was quite complex. Hence, based on their distribution, these species were subdivided into three groups in each major elevation group (Appendix 2). About one third of the Rhacophoridae species have wide distributional ranges (Appendix 2), of which, 10 species were noticeable: Pseudophilautus alto (Manamendra-Arachchi and Pethiyagoda, 2005), P. cavirostris (Günther, 1869), P. folicola (Manamendra-Arachchi and Pethiyagoda, 2005), P. fulvus (Manamendra-Arachchi and Pethiyagoda, 2005), P. popularis (Manamendra-Arachchi and Pethiyagoda, 2005), $P$. reticulatus (Günther, 1864) (Fig. 6), P. schmarda (Kelaart, 1854), P. singu (Meegaskumbura, Manamendra-Arachchi and Pethiyagoda, 2009), P. sordidus (Manamendra-Arachchi and Pethiyagoda, 2005), and P. stictomerus (Günther, 1876). By summarizing this data (Appendix 2 ), it is speculated that the species distribution data are insufficient on the genus Pseudophilautus. Hence, a need for further studies to understand their distribution patterns is hereby suggested. 


\section{Discussion}

\section{Recent taxonomic changes}

Frost et al. (2006) named a new genus Duttaphrynus for previously recognized Bufo melanostictus group (sensu Inger, 1972). Only Bufo melanostictus and B. noellerti were placed in this new genus from Sri Lanka. Other small to medium-sized Sri Lankan species (Bufo atukoralei Bogert and Senanayake, 1966, B. kotagamai Fernando and Dayawansa, and B. scaber (Schneider, 1799)) were not allocated to Duttaphrynus (Frost et al., 2006). Subsequently, Van Bocxlaer et al. (2009) showed that Bufo atukoralei, B. kotagamai and B. scaber are in fact members of Duttaphrynus. Apart from the above mentioned species, two other species from the family Bufonidae exist and they belong to an endemic genus Adenomus, sc., A. kelaartii and A. kandianus (Wickramasinghe et al., 2012b; Meegaskumbura et al., 2015). Until Wickramasinghe et al. (2012b) rediscovered the latter species, it was considered as an extinct species (Manamendra-Arachchi and Pethiyagoda, 1998). Moreover, Meegaskumbura et al. (2015) showed that previously described Adenomus dasi ManamendraArachchi and Pethiyagoda, 1998 is a new junior synonym of A. kandianus. Also, recent studies revealed that Duttaphrynus atukoralei is conspecific with D. scaber and the population that inhabits the Lowland Wet Zone (Fig. 7) is a distinct cryptic species related to D. scaber (Jayawardena et al., 2017).

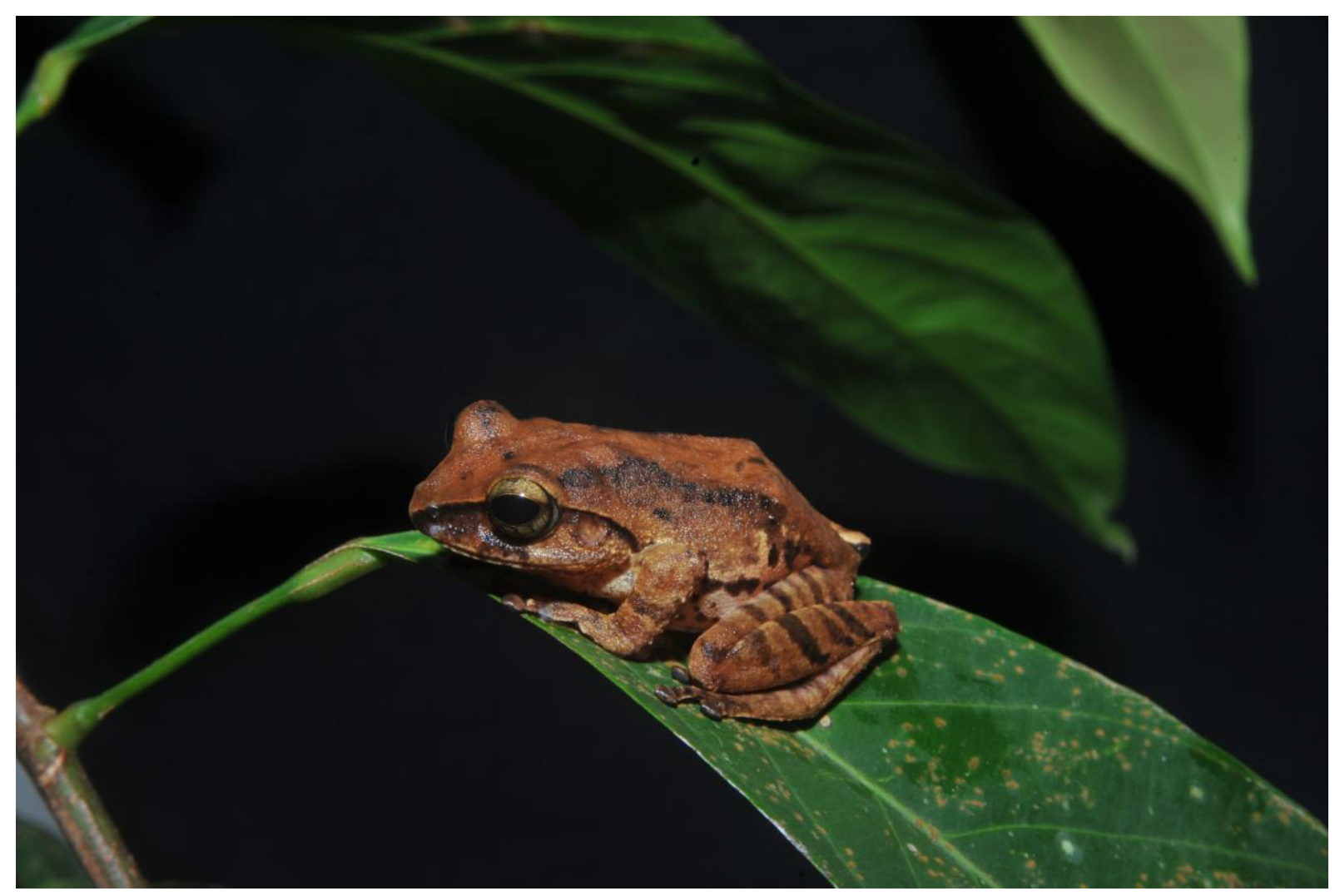

Figure 6: Pseudophilautus reticulatus, from the Dediyagala Forest Reserve, Lowland Wet Zone. Photo by WCSG. 


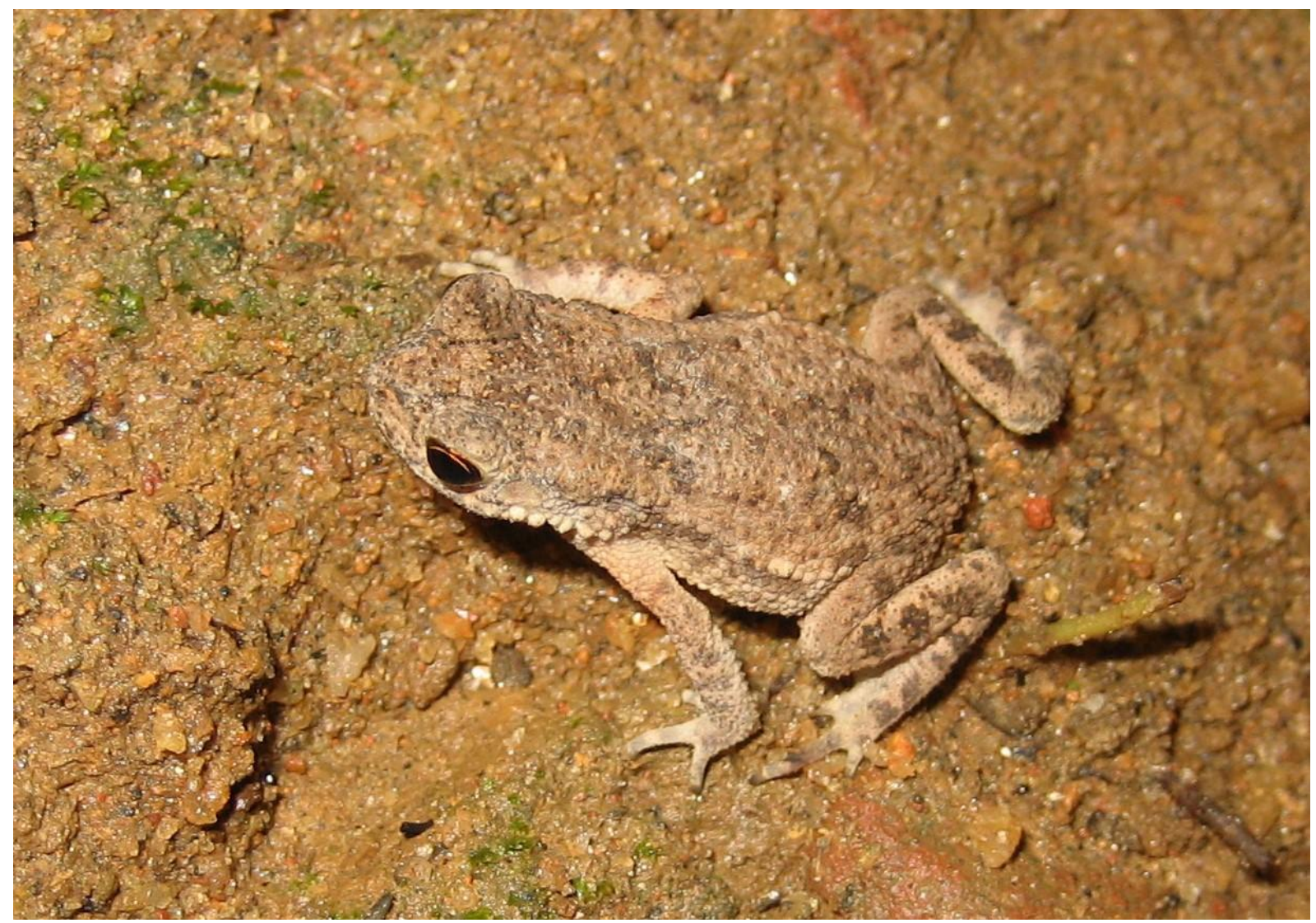

Figure 7: Duttaphrynus cf. scaber, from Thalalla near Matara, Lowland Wet Zone. Photo by Sudesh Batuwita.

In 2007, Fernando et al. (2007) described a new species of Nannophrys from Sri Lanka. This species is the only member of the congeners that occur in the Dry Zone. Taxonomy and phylogeny of the Asian Dicroglossidae species have been well studied recently (Alam et al., 2008; Biju et al., 2014; Khajeh et al., 2014; Oliver et al., 2015; Sanchez et al., 2018; Chandramouli et al., 2019). On the basis of these studies, Sri Lankan members of the genus Fejervarya Bolkay, 1915 are now placed in a different genus, Minervarya Dubois, Ohler and Biju, 2001 (Sanchez et al., 2018). Sanchez et al. (2018) allocated the Southeast Asian species in the genus Fejervarya and the South Asian species to the genus Minervarya. Based on recent studies (Sanchez et al., 2018; Chandramouli et al., 2019), three species of Minervarya are known from Sri Lanka, sc., M. greenii, M. kirtisinghei, and M. agricola. The latter species was previously known as Fejervarya limnocharis (Gravenhorst, 1829) (ManamendraArachchi and Pethiyagoda, 2006) and has recently been assigned to M. syhadrensis (Annandale, 1919), but now it is known as M. agricola (Sanchez et al., 2018; Chandramouli et al., 2019). Recently, a cryptic new species was described from the endemic genus Lankanectes, L. pera from the Knuckles Range (Senevirathne et al., 2018).

Sri Lankan frog species that have been previously placed in the genus Rana Linnaeus, 1758 (Manamendra-Arachchi and Pethiyagoda, 2006) were recently revised and also allocated to the genus Hylarana Tschudi, 1838 (Biju et al., 2014). In 2015, the phylogeny of this group was revised again and found that, two genera occur in Sri Lanka, sc., Hydrophylax Fitzinger, 1843 and Indosylvirana Oliver, Prendini, Kraus and Raxworthy, 2015 (Oliver et al., 2015). On the basis of above studies, the following species are recorded from Sri Lanka: Indosylvirana serendipi, I. temporalis and Hydrophylax gracilis (Biju et al., 2014; Oliver et al., 2015; Frost, 2018). Indosylvirana aurantiaca (Boulenger, 1904) has long been reported 
from Sri Lanka (Kirtisinghe, 1957; Dutta and Manamendra-Arachchi, 1996; ManamendraArachchi and Pethiyagoda, 2006), however, Biju et al. (2014) stated that this species is confined to India.

A recent study revealed that the Sri Lankan skipper frog belongs to the newly described Euphlyctis mudigere (Joshy et al., 2009; Khajeh et al., 2014). This species has a wide distribution range in India and Sri Lanka (Alam et al., 2008; Khajeh et al., 2014). In addition, Dahanukar et al. (2017) resurrected Sphaerotheca pluvialis (Jerdon, 1853) and mentioned that a few specimens from Sri Lanka, which they have examined, belong to this species. Hence, according to Dahanukar et al. (2017) three species of the genus Sphaerotheca Günther, 1859 are found in Sri Lanka: S. breviceps, S. pluvialis and S. rolandae. Dahanukar et al. (2017) placed Sphaerotheca rolandae in their breviceps group. Interestingly, based on the keys of Dahanukar et al. (2017), Sri Lankan material referred to S. rolandae, which depicted in Dutta and Manamendra-Arachchi (1996; fig. 154) affine to the dobsoni group. Hence, we speculate this material might belong to Sphaerotheca pluvialis from Sri Lanka. However, we did not include this species in our species list. Comprehensive studies on the genus in Sri Lanka may reveal their taxonomy.

Peloso et al. (2016) reviewed the higher-level taxonomy of the family Microhylidae. Except the species of the genus Microhyla Tschudi, 1838, all Sri Lankan species of the family Microhylidae are now placed in Uperodon Duméril and Bibron, 1841 (Peloso et al., 2016). However, Peloso et al. (2016) further mentioned that Kaloula Gray, 1831 is paraphyletic and the South Asian (Sri Lankan+Indian) populations of this genus can be separated from the Southeast Asian populations. Moreover, external morphology of these species (i.e., Sri Lankan Uperodon sensu Peloso et al.) showed distinguishable characters that can separate them into different genera as previously recognized (Dutta and Manamendra-Arachchi, 1996; Manamendra-Arachchi and Pethiyagoda, 2006). Hence, future integrated taxonomic approaches, including the internal morphology (e.g., osteology) will reveal the identity of supra-specific level taxonomy of them. Two new cryptic species were also recently added to the family Microhylidae: Microhyla mihintalei Wijayathilaka, Garg, Senevirathne, Karunarathna, Biju, and Meegaskumbura, 2016; and Uperodon rohani Garg, Senevirathne, Wijayathilaka, Phuge, Deuti, Manamendra-Arachchi, Meegaskumbura, and Biju, 2018 (Wijayathilaka et al., 2016; Garg et al., 2018).

The South and Southeast Asian shrub frogs, which were previously referred to Philautus, were placed in two separated genera (Yu et al., 2010). Yu et al. (2010) resurrected Pseudophilautus for the South Asian species. In the same year, Biju et al. (2010) described a new genus, Raorchestes Biju, Shouche, Dubois, Dutta, and Bossuyt, 2010. Biju et al. (2010) placed most of the Indian Pseudophilautus species in Raochestes and mentioned only three species of Pseudophilautus from India. In 2007, based on museum material, two new extinct species of Pseudophilautus were described from Sri Lanka (Meegaskumbura et al., 2007), sc., $P$. maia (Meegaskumbura, Manamendra-Arachchi, Schneider, and Pethiyagoda, 2007) and $P$. pardus (Meegaskumbura, Manamendra-Arachchi, Schneider, and Pethiyagoda, 2007). Wickramasinghe et al. (2012a; 2013a; 2015) also added many rhacophorid species to the assemblage of amphibians of Sri Lanka, which includes a new species of Polypedates as well. Interestingly, Wickramasinghe et al. (2012b) uncovered Adenomus kandianus from the Peak Wilderness. In addition, Meegaskumbura et al. (2012a) provided detailed description of a Data Deficient Pseudophilautus semiruber. Apart from that, Wickramasinghe et al. (2013b, c) rediscovered two extinct Pseudophilautus species, $P$. stellatus (Kelaart, 1853), and $P$. hypomelas (Günther, 1876) from the Central Hills zoogeographic zone. Batuwita et al. (2019b) also described a new species of Pseudophilautus from Southern Sri Lanka (in the Lowland Wet Zone). 


\section{Doubtful or obscure records}

Taylor $(1965 ;$ 1969) described five species of Ichthyophis Fitzinger (Caecilians: Ichthyophiidae Taylor) from Sri Lanka, including: Ichthyophis forcati Taylor, 1965, I. glutinosus, I. orthoplicatus Taylor, 1965, I. pseudangularis Taylor, 1965, and I. taprobanicensis Taylor, 1969. However, Nussbaum and Gans (1980) synonymized Ichthyophis forcati and I. taprobanicensis under I. glutinosus and I. orthoplicatus, respectively. Subsequently, Gower et al. (2005) showed Sri Lankan caecilians represent a monophyletic clade and also uncovered a cryptic species from Sabaragamuwa Province. Gower et al. (2005) further stated that this cryptic species either might represents Taylor's (1965) Ichthyophis forcarti or might belong to a hitherto undescribed species. Taylor (1965) also mentioned a record of another species from Sri Lanka, Caudacaecilia asplenia (Taylor, 1965). This species has recently been allocated to Ichthyophis by Nishikawa et al. (2012). In addition, Carl Gans (unpublished data) announced an occurrence of Uraeotyphlus Peters species from Sri Lanka. A comprehensive review of the caecilians of Sri Lanka may confirm the validity of the above records and undescribed species.

Kirtisinghe (1957) mentioned records of Duttaphrynus stomaticus (Lütken, 1862) (three specimens [not examined by us], now in BMNH: 1932.5.7.2-3 [2ex.], 1955.1.10.85) from Mutwal $\left(06^{\circ} 57^{\prime} \mathrm{N}, 7^{\circ} 52^{\prime} \mathrm{E}\right)$ near Colombo. He considered that these specimens were transported to Sri Lanka by means of sailing vessels. Also, Dutta and ManamendraArachchi's (1996) records of Hoplobatrachus tigerinus (Daudin, 1802) from Sri Lanka were subsequently refuted by Dutta (1997) and considered that those Sri Lankan specimens are in fact misidentified specimens of Hoplobatrachus crassus.

\section{Endemic and extinct amphibians}

Sri Lankan amphibians are unique, as 90 percent of the species are endemics (ManamendraArachchi and Pethiyagoda, 2006; Fernando et al., 2007; Meegaskumbura et al., 2007; 2012a; Wickramasinghe et al., 2012a, b; 2013b, c; Meegaskumbura et al., 2015; Batuwita et al., 2019b). Up to now 120 species of amphibians have been recorded from Sri Lanka. Recent explorations have helped to reduce the number of extinct species from 21 (Adenomus kandianus, Nannophrys guentheri Boulenger, 1882 and 19 species of Pseudophilautus) to 18 (N. guentheri and 17 Pseudophilautus spp.). Three species that had been previously assigned to the extinct species list (Adenomus kandianus (misidentified as a new species by Manamendra-Arachchi and Pethiyagoda (1998)), Pseudophilautus hypomelas and $P$. stellatus) and the Data Deficient species (Pseudophilautus semiruber) were recently rediscovered (Wickramasinghe et al., 2012b; 2013b, c; Meegaskumbura et al., 2012a; 2015). The above recent rediscoveries of amphibians from Sri Lanka suggest the need for further surveys of other extinct species, especially the Pseudophilautus spp., because directdeveloping amphibians are less prone to threats (Stuart et al., 2004; Xie et al., 2007). This speculation is further confirmed by the discovery of certain other hitherto unknown species from Knuckles Range and Rakwana Hills (Figs. 8-10) (see also WCSG, 2008; 2009; Janzen and Bopage, 2011).

Nothing is known of the biology of the only other extinct Nannophrys guentheri, but its biology might be same as the other three living congeners (Clarke, 1983; Dutta and Manamendra-Arachchi, 1996; Manamendra-Arachchi and Pethiyagoda, 2006). Hence, the conservation of other congeners is mandatory. Clarke (1983) described the heavily ossified cranium condition that was observed in adults of Nannophrys ceylonensis and N. marmorata, but the same condition was not found in $N$. guentheri. And he suggested that the holotype of Nannophrys guentheri might be a juvenile specimen. However, it is not certain that the 
description of $N$. guentheri was based on a juvenile specimen of $N$. ceylonensis. Current distributions of all but Nannophrys naeyakai are within the Central Hills, Knuckles Range, and Lowland Wet Zone of Sri Lanka that have an ample supply of water (perennial streams) and humid conditions. Thus, the survival of these species will persist as long as adequate forest cover and perennial water bodies remain. Even though Nannophrys naeyakai was described from the Dry Zone of Sri Lanka, its habitats are much more similar to the habitats within the Central Hills, Knuckles Range and Lowland Wet Zone of Sri Lanka (i.e., with humid, shaded forests, perennial streams and also situated in relatively high elevations, 200$600 \mathrm{~m}$ (Fernando et al., 2007)).

In terms of higher number of extinct species (Table 3), the family Rhacophoridae represents the majority. Manamendra-Arachchi and Pethiyagoda (2005) suggested that these extinct species may be anthropogenic species that might have been collected from home gardens and their extinctions may be due to massive deforestation during the colonial period. However, in contrast to Manamendra-Arachchi and Pethiyagoda's (2005) suggestion, some anthropogenic species (habitat generalists) have been reported after the late 19th century, e.g., Pseudophilautus sarasinorum (Müller, 1887), P. pleurotaenia (Boulenger, 1904), and P. fergusonianus (Ahl, 1927) (Manamendra-Arachchi and Pethiyagoda, 2005). Moreover, Weerawardhena and Russell (2012) showed that about $48 \%$ of species were entirely from closed canopy (from forest), while all other species were habitat generalists. Thus, in an amphibian community, habitat generalists may be the majority and the most vulnerable members seem to be the habitat specialists (forest dwellers).

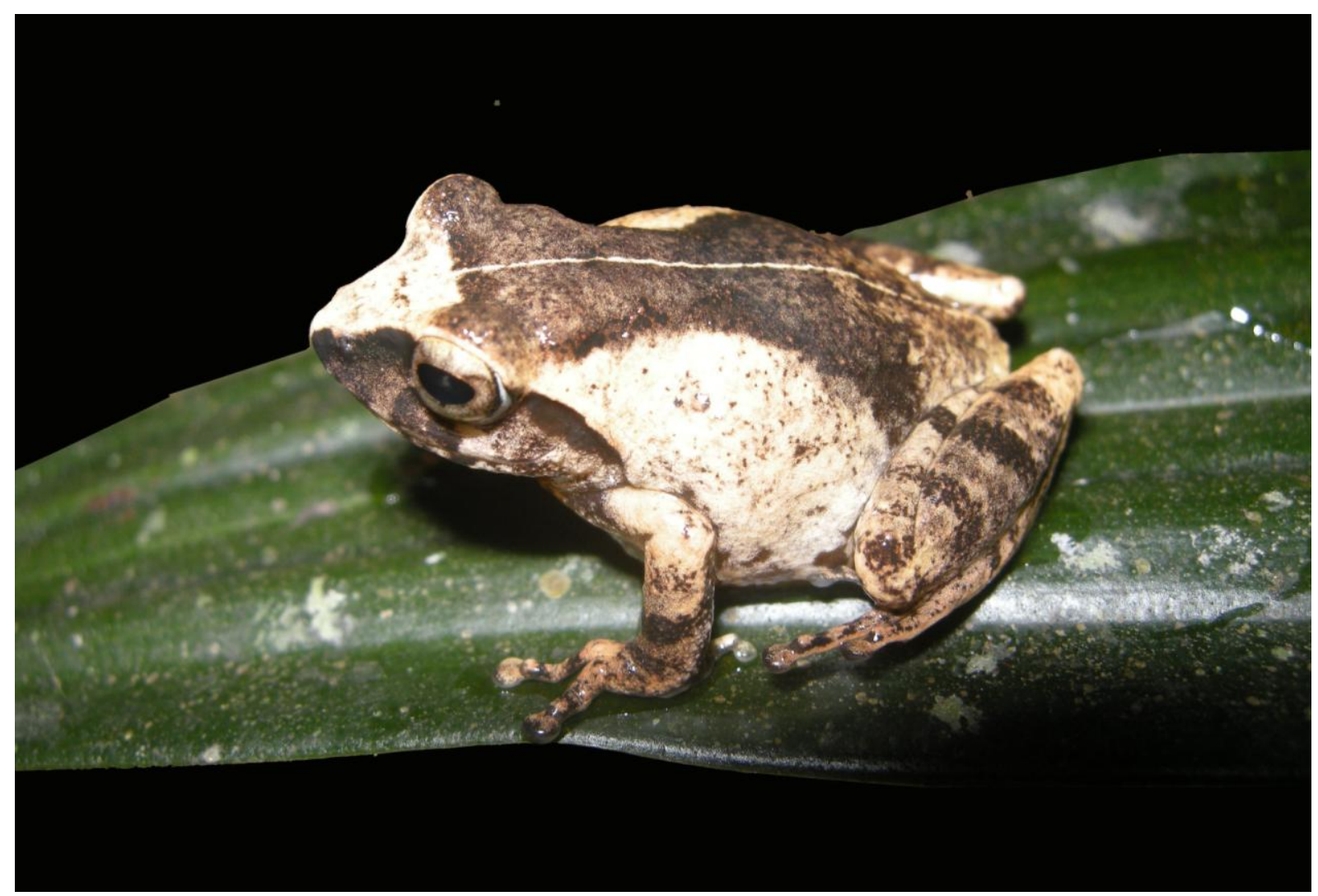

Figure 8: Pseudophilautus sp., from Riverstone, Knuckles Range. Photo by Sudesh Batuwita. 


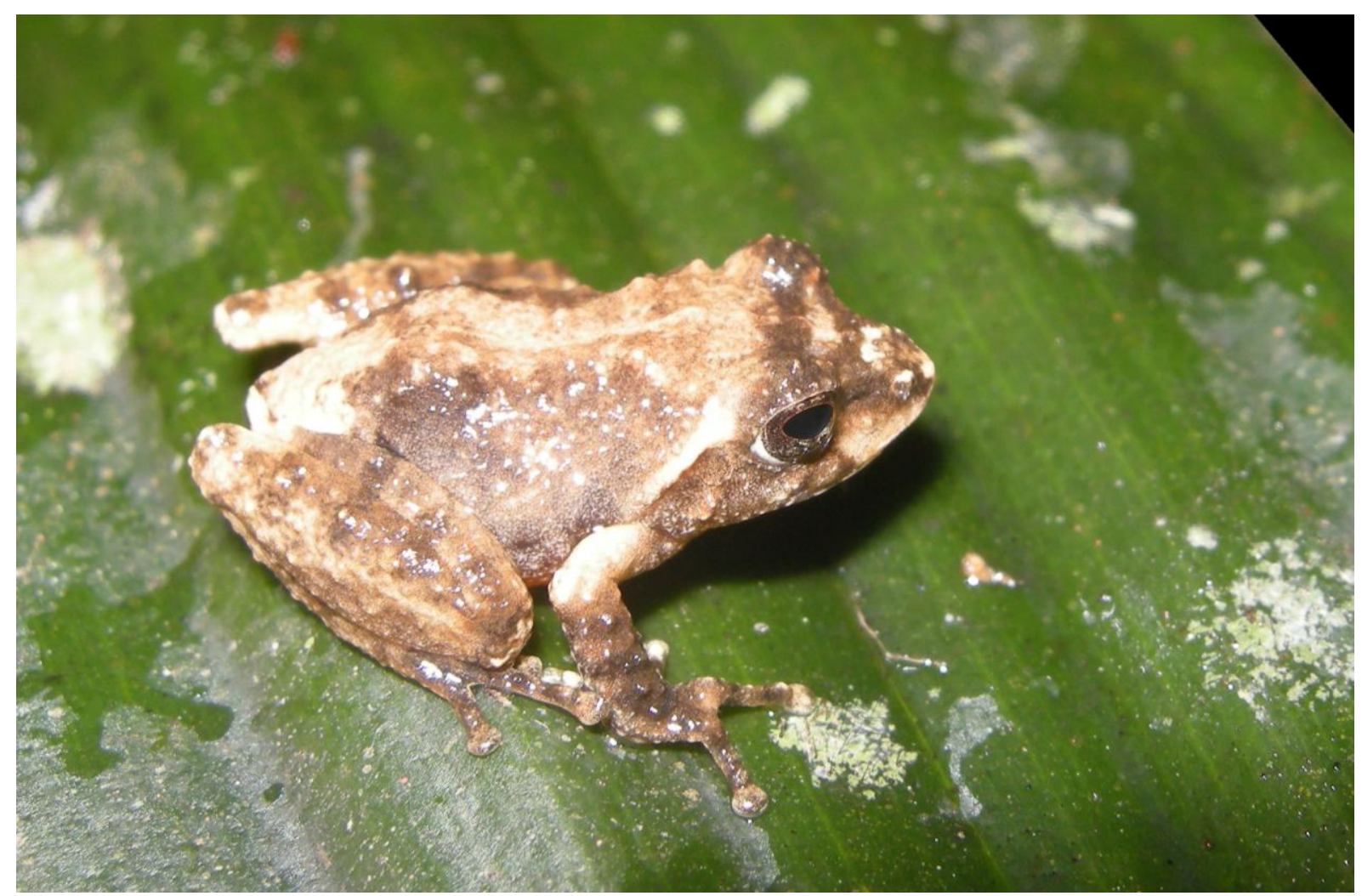

Figure 9: Pseudophilautus sp., from Riverstone, Knuckles Range. Photo by Sudesh Batuwita.

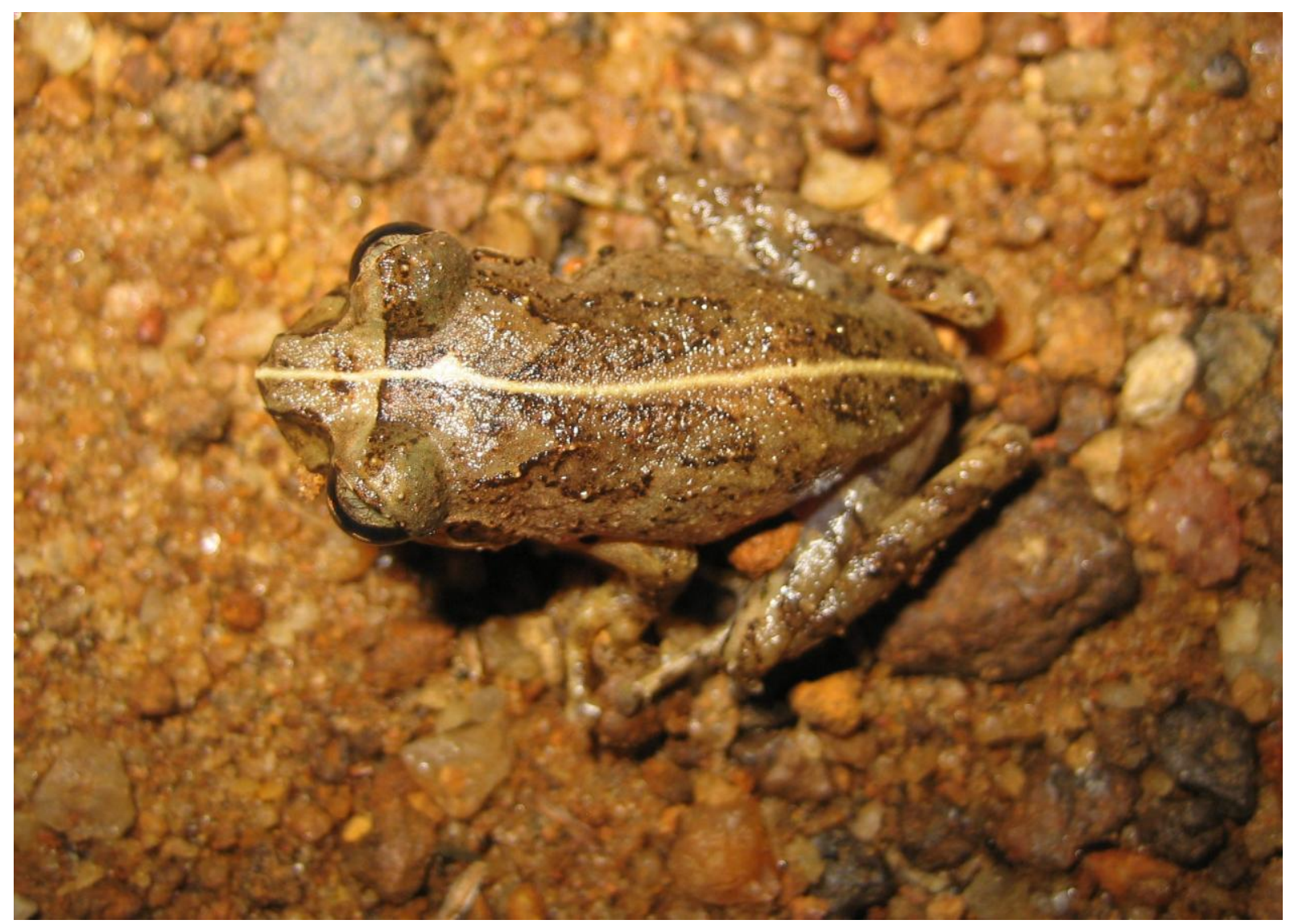

Figure 10: Pseudophilautus cf. sarasinorum, from the Morningside Forest Reserve, Rakwana Hills. Photo by Sudesh Batuwita. 
Although most of the species of Pseudophilautus showed the ground nesting breeding behavior (bury their fertilized eggs in loose soil; Bahir et al., 2005, figs. 2-3), a single species, $P$. femoralis and probably its sister species, P. mooreorum and P. poppiae (Meegaskumbura and Manamendra-Arachchi, 2005) exhibit the leaf-nesting behavior (Bahir et al., 2005, fig. 4). These three species were known as endangered species (Manamendra-Arachchi and Pethiyagoda, 2005; Meegaskumbura and Manamendra-Arachchi, 2005). Even though the distribution of Pseudophilautus femoralis was restricted to undisturbed high elevational forests in the Central Hills (Manamendra-Arachchi and Pethiyagoda, 2005), it was found from Uda Malibada $\left(06^{\circ} 53^{\prime} 01^{\prime}{ }^{\prime} \mathrm{N}, 80^{\circ} 26^{\prime} 31^{\prime \prime} \mathrm{E}\right)$ in the Peak Wilderness at an elevation of $700 \mathrm{~m}$ (Peabotuwage et al., 2012). Therefore, Pseudophilautus femoralis is no longer confined to the higher areas of Central Hills as mentioned by Manmendra-Arachchi and Pethiyagoda (2005). Hence, this leaf nesting behaviour may even occur in other places like Uda Malibada (not in montane forests). Moreover, Pseudophilautus femoralis has also been recorded from secondary forests (Bahir et al., 2005; pers. obs.).

Yet another point needs to be considered when investigating the extinct species, and that is the preponderance of Sri Lanka's amphibian fauna due to the recent discoveries of arboreal/semiarboreal rhacophorids. This species number is quite unusual by the standards of the other known Sri Lankan amphibian fauna (Fig. 2A). However, the direct development breeding behavior of Pseudophilautus might help the existence of a large number of species (Bogart, 1981; Meegaskumbura et al., 2019). Manamendra-Arachchi and Pethiyagoda (2005) allocated all rhacophorids (then as Rhacophorinae Hoffman) that showed direct development breeding mode to the genus Philautus (= Pseudophilautus) and also recognized 52 species. However, numbers of previously described species, which have long been disputed due to lack of recent material were a handful in their study, 10 out of 25 (Manamendra-Arachchi and Pethiyagoda, 2005; Table 1). Moreover, it was mentioned above (in the Results section) there are certain species, which have wide distribution ranges (Appendix 2): Pseudophilautus alto, P. cavirostris, $P$. folicola, $P$. fulvus, $P$. popularis, $P$. reticulatus, $P$. schmarda, $P$. singu, $P$. sordidus, and $P$. stictomerus. Out of 10 of these species, six species were recently described (Manamendra-Arachchi and Pethiyagoda, 2005; Meegaskumbura et al., 2009). Hence, it is remarkable why these rather common (see Appendix 2) species had not been collected during the colonial period. Therefore, based on these observations and data, it is concluded that some of the other extinct species either have to be rediscovered (Data Deficient) or most probably were misidentified as other species (Udugampala and Batuwita, in prep.).

Interestingly, it was observed (see also Batuwita et al., 2019b) that certain characters have intraspecific variations in Pseudophilautus, e.g., presence or absence of the median lingual process. In addition, we uncovered another character that was used to diagnose species, that is apparently due to the sexual dimorphism, e.g., horn-like spinules on dorsum, (ManamendraArachchi and Pethiyagoda, 2005) and the third one or the condition that might wrongly be interpreted or identified in the previous works is calcar vs. tarsal tubercle and/ or presence vs. absence of this character/s (Manamendra-Arachchi and Pethiyagoda, 2005; Meegaskumbura et al., 2007). On the basis of our data of the species with this character (calcar/ tarsal tubercle) this also appears to be due to sexual dimorphism i.e., either well-developed or weakly developed/ rudimentary (Udugampala and Batuwita, in prep.).

\section{Threats, conservation and recommendations}

Sri Lanka's cloud forests are restricted to above $\sim 1000 \mathrm{~m}$ a.s.l. within the three major zoogeographic zones (i.e., Central Hills, Knuckles Range, and Rakwana Hills). In terms of area of remaining natural habitats, Beralagala, Gongala Hills, Hadapan Ella Plains, 
Kabaragala, and Suriyakanda, are the smallest forests in the Rakwana Hills, but they harbour most of the point endemic species (Manamendra-Arachchi and Pethiyagoda, 2006).

Massive deforestation during the colonial period has resulted in severe threats to the fauna in Sri Lanka (Pethiyagoda and Manamendra-Arachchi, 1998; Manamendra-Arachchi and Pethiyagoda, 2005). At present, the same threat occurs due to agricultural practices in and around remnant forest reserves (often near to forest borders/ buffer zones). Encroachments around buffer zones and further exploitation of forests are the major threats (Bahir and Surasinghe, 2005). This leads to reduction of forest cover, fragmentation and eventually loss of unique habitats (Bahir and Surasinghe, 2005). Consequently, it affects most habitat specialists due to the invasions of anthropogenic species (e.g., Duttaphrynus melanostictus [found in many rain forests buffer zones], D. scaber [observed in Hiyare Forest reserve and Oliyagankele Forest reserve], Minervarya agricola, Pseudophilautus tanu (Meegaskumbura, Manamendra-Arachchi, and Pethiyagoda, 2009), P. schneideri Meegaskumbura and Manamendra-Arachchi, 2011 [Dediyagala Forest Reserve], P. popularis, P. rus (Manamendra-Arachchi and Pethiyagoda, 2005) [Gannoruwa Forest reserve]). Loss of forest cover (e.g., deforestation, due to anthropogenic forest fires) causes streams to dry (perennial water bodies) within forests or adjoining them, which in turn limit the distribution and reproduction of amphibians (e.g., fragmented forest patches in the Lowland Wet Zone and Central Hills: Atamassakanda, Gannoruwa, Kunduppakanda, Rumasswala; Batuwita, 2000; Batuwita and Bahir, 2005; WCSG, 2008; 2009).

Apart from the Dry Zone, rapid increase of human population in the other zones of Sri Lanka (Anon., 2003) cause the loss of habitats of fauna and flora. Myers et al. (2000) estimated that the Western Ghats range of mountains together with Sri Lanka has lost more than $70 \%$ of its original habitat due to the rapid growth of human population. Even though the Dry Zone zoogeographic zone is larger than others, only two restricted species are found in this zone, sc., Nannophrys naeyakai and Pseudophilautus regius. Most of the endangered and threatened amphibian species are restricted to the forests (some even fragmented) within the highly populous districts like Galle, Kalutara, Kandy, Matara, and Nuwaraeliya. Due to increase in infrastructure in these highly populous areas, more destruction occurs, e.g., clearing of wetland vegetation and forest borders/ buffer zones (Karunarathna et al., 2016). Thus, the forest reserves/ wetlands are fragmenting. This may lead to diminishing of the gene pool of particular species due to inbreeding depression (Perl et al., 2018). Therefore, without having a potential gene pool, certain species with restricted distributions may become extinct in the future. Recent studies (e.g., Bierregaard et al., 2001; Brook et al., 2003; Ferraz et al., 2003) have shown that extreme rain forest fragmentation could lead to catastrophic declines and extinctions of species in decadal time frames.

Irrational infrastructure developments, passively cause loss of amphibians due to road-kills in Sri Lanka: this accounts for not only loss of amphibians but also the other fauna as well (Maduwage et al., 2003; Karunarathna et al., 2017). In Sri Lanka, anthropogenic noise is a little known threat to the amphibians, which are living beside roads. Anthropogenic noise alters the behaviour of amphibian populations (Sun and Narins, 2005; Kaiser and Hammers, 2009; Kaiser et al., 2011; Caorsi et al., 2017). A case study showed that male frogs, which have been exposed to anthropogenic noise, exhibited both a decrease in days performing chorus and chorus duration at night (Kaiser et al., 2011). According to Kaiser et al. (2011), this may substantially affect the reproductive success because females generally join choruses late at night to breed.

Distribution of Duttaphrynus melanosticus in all zoogeographic zones is remarkable (from coast to $\sim 1700 \mathrm{~m}$ a.s.1.) (Manamendra-Arachchi and Pethiyagoda, 2006). Interspecific competition of anurans and their larvae has been reported (De Benedictis, 1974; Seale, 1980; 
Sredl and Collins, 1992). Due to deforestation, anthropogenic species like Duttaphrynus melanostictus undoubtedly compete with threatened or uncommon species for food, space and for breeding sites: e.g., with Duttaphrynus cf. scaber and Polypedates cruciger (Blyth, 1852) in the Lowland Wet Zone; with Microhyla zeylanica Parker and Osman Hill, 1948, Uperodon obscurus (Günther, 1864), U. palmatus and Minervarya greenii in the Central Hills; and with Microhyla karunaratnei and Uperodon obscurus in the Rakwana Hills.

A recent study showed that invasive alien species like the guppy fish (Poecilia spp.) feed on amphibian eggs (Bambaradeniya, 1999). Studies on the impact of invasive alien fish species on amphibians are limited in Sri Lanka (Bambaradeniya, 1999). Hence, studies should be extended, especially on the invasive exotic fish species of the genus Oreochromis, which breed in brackish water and also due to their island-wide distribution (Pethiyagoda, 1991).

In Sri Lanka, water bodies are polluted with high loads of water-soluble chemicals (Amarasekara et al., 2013). According to Amarasekara et al. (2013), a massive volume of polluted water is discharged into natural water bodies in the hills during the monsoon. Due to this polluted water, middle and lower streams contaminate and may cause severe problems for aquatic fauna and flora. Stream or river associated (breed in water and/or live in semiaquatic habitats) malformed amphibians have been reported from Sri Lanka as well (WCSG, 2008; De Silva, 2011). These malformed stream-associated amphibians might breed in polluted waters (Gower et al., 2005; Taylor et al., 2005; Gurushankara et al., 2007). Parasitic attacks on amphibians were also reported (Rajapaksa and De Silva, 2001). This may be due to pollution in the particular areas as described by Johnson et al. (2007).

Fortunately, no records of chytridiomycosis have been reported in Sri Lanka (Surasinghe, 2009). However, as an infectious disease in the high-elevation inhabiting and stream-breeding species (Pounds and Puschendorf, 2004), Batrachochytrium dendrobatidis will drastically affect the following threatened species: Adenomus kandianus, Taruga eques (Günther, 1858), Uperodon palmatus, and Microhyla zeylanica in the Central Hills. As an example, Min et al. (2011) mentioned that chytridiomycosis in South Korea is due to the introduction (for consumption) of American bullfrog, Lithobates catesbeianus (Shaw, 1802). Lithobates catesbeianus is one of the 'Black list' invasive alien species of Sri Lanka as well (Silva and Kurukulasuriya, 2010). Lithobates catesbeianus has shown the highest prevalence, about $18 \%$, for Batrachochytrium dendrobatidis (Min et al., 2012). Fortunately, as a cultural taboo, amphibians are not consumed as a food item in Sri Lanka. The wildlife trade is a severe threat to amphibians, because some invasive exotic species have been introduced to Sri Lanka through wildlife trade as pets (Silva and Kurukulasuriya, 2010). As a recent example, the urodelan pathogen, Batrachochytrium salamandrivorans has been introduced to Europe through wild anuran trade (Nguyen et al., 2017).

The most recent and growing threat to the fauna and flora in the world is climate change. In Sri Lanka, changes in weather patterns have become more pronounced in the past few decades, i.e., shifting or decrease of monsoon rainfall, floods, landslides, and prolonged droughts (Basnayake, 2007; De Costa, 2008). Climate change may drastically affects the amphibian fauna of Sri Lanka (Bahir et al., 2005; Kottawa-Arachchi and Wijeratne, 2017). As an example, it was observed that Taruga longinasus (Ahl, 1931) breeds in lentic habitats that are adjacent to lotic habitats in the Kanneliya Forest reserve. These shallow lentic habitats were situated parallel to the stream and with a litter layer at the bottom. Hundreds of tadpoles were observed in these pools. It was also observed about 15 males and two females of Taruga longinasus in the particular area and it is believed that the presence of regular precipitation might be needed for the formation of such lentic habitats. Especially, that species with aquatic breeding phase (except Pseudophilautus spp.) may drastically get affected by abrupt changes 
in rainfall, e.g., prolonged droughts, devastating torrential rains (Taigen et al., 1984; Seymour, 1999; Ryan et al., 2015).

Werner (1988) reported forest dieback in the Nuwaraeliya District in the late 20th century and speculated that cloud forest dieback in the Horton Plains and in Hakgala might be due to climate change. The same situation was recently observed in the Rakwana Hills, in the Morningside Forest reserve.

When considering the point endemics or restricted species, it is mandatory to initiate population viability tests in order to ascertain their survival and also document their new distribution record data. Interestingly, certain species, which had long been considered as point endemics or restricted species to a few localities were subsequently reported from new localities, viz., Pseudophilautus alto, P. asankai (Manamendra-Arachchi and Pethiyagoda, 2005), P. auratus (Manamendra-Arachchi and Pethiyagoda, 2005), P. cavirostris, P. femoralis, P. nemus (Manamendra-Arachchi and Pethiyagoda, 2005), Taruga eques, and Uperodon nagaoi (Manamendra-Arachchi and Pethiyagoda, 2001) (Kandamby, 2001; Kandamby and Batuwita, 2001; WCSG, 2008; 2009; Bopage et al., 2011; Janzen and Bopage, 2011; Peabotuwage et al., 2012). In 2004, the Wildlife Conservation Society-Galle of Sri Lanka (WCSG) initiated a conservation program for the threatened Uperodon nagaoi in the fragmented Hiyare Forest reserve (De Silva, 2006), by providing artificial breeding grounds (water filled tree holes), because in the wild, Uperodon nagaoi breeds in phytotelmic habitats (Manamendra-Arachchi and Pethiyagoda, 2001a; De Silva, 2006). Within a few weeks the project goal was achieved: the attached cement-made water holes were accepted by Uperodon nagaoi individuals and they bred in artificial habitats (Fig. 11).

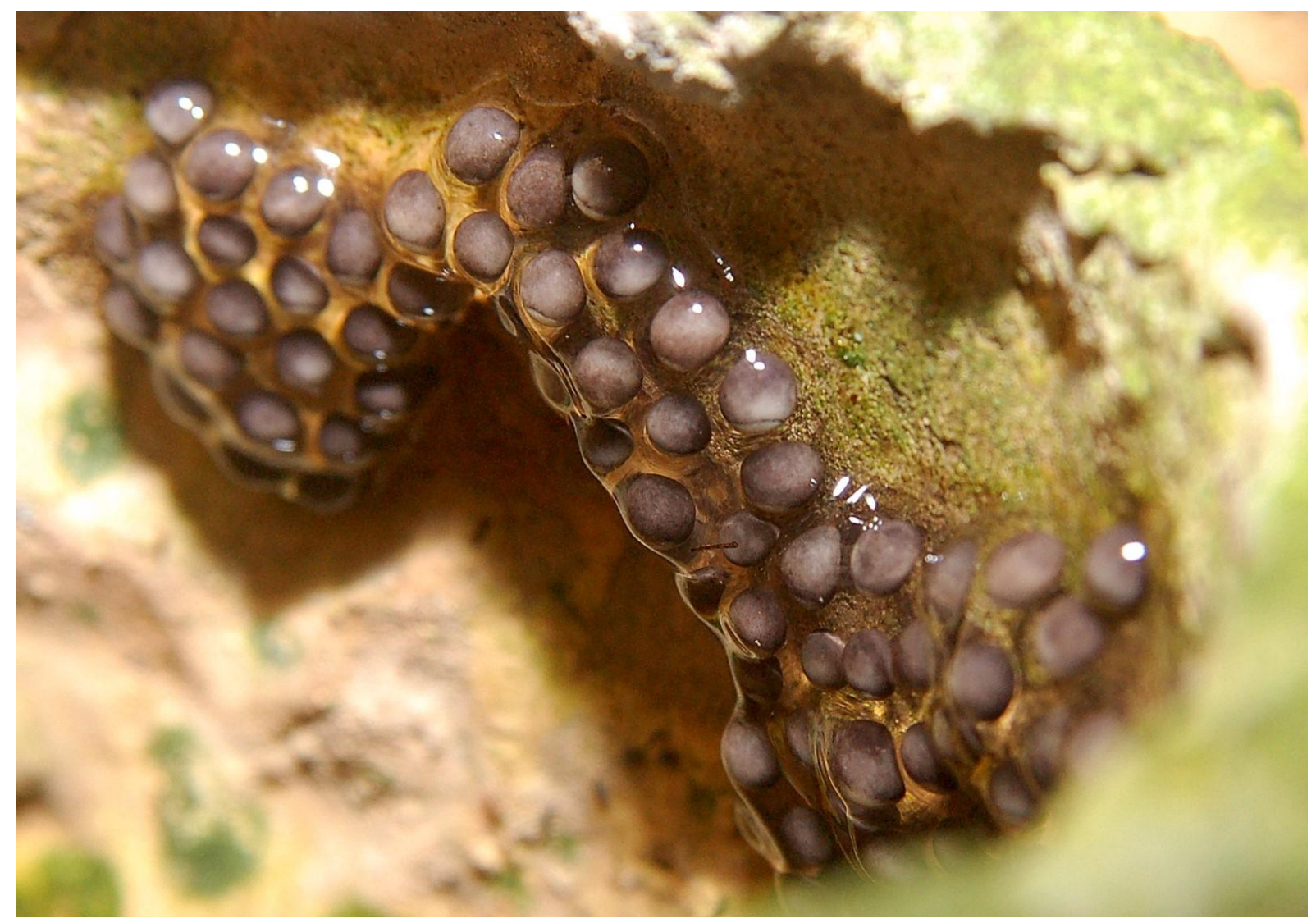

Figure 11: Uperodon nagaoi, developing embryos in an artificial breeding apparatus. Photo by WCSG. 
This project can be used as a base study for the future conservation programs for the other related threatened species, viz., Uperodon palmatus with similar behavior. Recently, ecology and demography of Adenomus kandianus were assessed in the Peak Wilderness (Karunarathna et al., 2016). Karunarathna et al. (2016) mentioned the need for further studies to assess their breeding biology and population viability. Also, Janzen and Bopage (2011) stated that there is a lack of studies on the distribution and ecology of amphibians in Sri Lanka. Most recently, De Silva and Wijayathilaka (2019) discussed bioacoustics and its applications for conservation of amphibians. Therefore, it is mandatory to assess Sri Lankan amphibians' distribution, population viability (especially for threatened species with restricted distributions), and breeding biology behaviors in order to conserve them in the future.

\section{Conclusions}

Sri Lankan amphibian fauna comprises 120 species, of which 108 are endemics. On the basis of their distribution, five zoogeographic zones were introduced, viz., Central Hills, Dry Zone, Knuckles Range, Lowland Wet Zone, and Rakwana Hills. The species composition of each zone is recorded. The highest number of species was reported from the Central Hills (53 species). The Rakwana Hills represented the highest threatened species (83\%), whereas the Dry Zone had both lowest numbers of endemic and threatened species. Species diversity along the elevational gradient was also reported with the highest species assemblages around 0 to $1300 \mathrm{~m}$ elevation. Some reasons for the presence of many extinct species appears to be due to misidentifications or lack of studies. Sri Lankan amphibians face the following multiple threats due to the island effect: forest fragmentation, increasing human population, exotic species, pollution, and climate change.

\section{Acknowledgments}

This work was partially supported by the Nagao Natural Environment Foundation (NEF), Japan, the Postgraduate Institute of Agriculture of Sri Lanka (PGIA), the Biodiversity Secretariat (BDS) of the Ministry of Environment and Natural Resources and the Nations Trust Bank PLC Sri Lanka. We would like to thank all staff at the Biodiversity Heritage Library (BHL) for facilitating easy access to the old and most difficult literature to trace. Sudesh Batuwita and Jiaojiao Diao thank Judha Mantu (PNG Forest Authority), Khone Soukphaxay and Huang Kairu (Nanjing Forestry University) for their assistance in the preparation of the manuscript. Finally, we are grateful to Theodore J. Papenfuss (University of California, Berkeley) and Ali Gholamifard (Lorestan University) for criticisms and helpful suggestions that helped substantially to improve the quality of this manuscript.

\section{References}

Ahl, E. (1927). Zur systematik der asiatischen arten der frosch gattung Rhacophorus. Sitzungsberichte der Gesellschaft Naturforschender Freunde zu Berlin, 1927: 35-47.

Alam, M. S., Igawa, T., Khan, M. M. R., Islam, M. M., Kuramoto, M., Matsui, M., Kurabayashi, A. and Sumida, M. (2008). Genetic divergence and evolutionary relationships in six species of genera Hoplobatrachus and Euphlyctis (Amphibia: Anura) from Bangladesh and other Asian countries revealed by mitochondrial gene sequences. Molecular Phylogenetics and Evolution, 48 (2): 515-527. https://doi.org/10.1016/j.ympev.2008.04.020

Amarasekara, M. G. T. S., Dayawansa, N. D. K. and De Silva, R. P. (2013). Stream water quality depletion under intensive agriculture. South Asian Water Studies, 4 (1): 23-37. 
Anderson, J. (1871). A list of the reptilian accession to the Indian Museum, Calcutta from 1865 to 1870, with a description of some new species. The Journal of the Asiatic Society of Bengal, 40: 12-39.

Annandale, N. (1913). Some new and interesting Batrachia and lizards from India, Ceylon and Borneo. Records of the Indian Museum, 9: 301-307.

Annandale, N. (1919). The fauna of certain small streams in the Bombay Presidency: some frogs from streams in the Bombay Presidency. Records of the Indian Museum, 16: 109161.

Anonymous (1995). Sri Lanka Forestry Sector Master Plan. Forestry planning unit, Ministry of agriculture, land and forestry, Colombo, Sri Lanka. 511 pp.

Anonymous (2003). Statistical Pocket Book 2003. Department of Census and Statistics, Colombo, Sri Lanka. 100 pp.

Ashton, M. S., Gunatilleke, S., de Zoysa, N., Dassanayake, M. D., Gunatilleke, N. and Wijesundera, S. (1997). A field guide to the common trees and shrubs of Sri Lanka. WHT Publications (Pvt.) Ltd, Colombo, Sri Lanka. 432 pp.

Bahir, M. M. and Silva, A. (2005). Otocryptis nigristigma, a new species of agamid lizard from Sri Lanka. The Raffles Bulletin of Zoology, 12: 393-406.

Bahir, M. M. and Surasinghe, T. (2005). A conservation assessment of the agamid lizards of Sri Lanka. The Raffles Bulletin of Zoology, 12: 407-412.

Bahir, M. M., Meegaskumbura, M., Manamendra-Arachchi, K., Schneider, C. J. and Pethiyagoda, R. (2005). Reproduction and terrestrial direct development in Sri Lankan shrub frogs (Ranidae: Rhacophorinae: Philautus). The Raffles Bulletin of Zoology, 12: 339-350.

Bambaradeniya, C. N. B. (1999). Alien invasive fauna in natural habitats and their impact on indigenous biota, In: Marambe, B. (Ed.), Proceedings of the First National Workshop on Alien Invasive Species in Sri Lanka. Ministry of Forestry and Environment, Sri Lanka. pp. $45-51$.

Basnayake, B. R. S. B. (2007). Climate change, In: Anonymous, The National Atlas of Sri Lanka. Government Press Sri Lanka, Colombo. pp. 54-55.

Batuwita, S. (2000). Lizards of Mount Gannoruwa. Loris, 22 (3): 13-15.

Batuwita, S. (2019). A review of the lizards of the endemic genus Lankascincus (Reptilia: Scincidae: Lygosominae) from Sri Lanka. Bulletin of the Museum of Comparative Zoology, 162 (3): 211-262. https://doi.org/10.3099/MCZ38.1

Batuwita, S. and Bahir, M. M. (2005). Description of five new species of Cyrtodactylus (Reptilia: Gekkonidae) from Sri Lanka. The Raffles Bulletin of Zoology, 12: 351-380.

Batuwita, S. and Udugampala, S. (2017). Description of a new species of Cnemaspis (Squamata: Gekkonidae) from Knuckles Range of Sri Lanka. Zootaxa, 4254 (1): 82-90. http://doi.org/10.11646/zootaxa.4254.1.4

Batuwita, S., Agarwal, I. and Bauer, A. M. (2019a). Description of a new diminutive, rupicolous species of day-gecko (Squamata: Gekkonidae: Cnemaspis) from southern Sri Lanka. Zootaxa, 4565 (2): 223-234. http://dx.doi.org/10.11646/zootaxa.4565.2.6

Batuwita, S., De Silva, M. and Udugampala, S. (2019b). Description of a new species of Pseudophilautus (Amphibia: Rhacophoridae) from southern Sri Lanka. Journal of Threatened Taxa, 11 (1): 13120-13131. https://doi.org/10.11609/jott.3903.11.1.1312013131 
Bierregaard, R. O., Gascon, C., Lovejoy, T. E. and Masquita, R. (2001). Lessons from Amazonia: the ecology and conservation of a fragmented forest. Yale University Press, New Haven, Connecticut, and London, United Kingdom. 496 pp.

Biju, S. D., Garg, S., Mahony, S., Wijayathilaka, N., Senevirathne, G. and Meegaskumbura, M. (2014). DNA barcoding, phylogeny and systematics of Golden-backed frogs (Hylarana, Ranidae) of the Western Ghats-Sri Lanka biodiversity hotspot, with the description of seven new species. Contributions to Zoology, 83 (4): 269-335. https://doi.org/10.1163/18759866-08304004

Biju, S. D., Shouche, Y. S., Dubois, A., Dutta, S. K. and Bossuyt, F. (2010). A grounddwelling rhacophorid frog from the highest mountain peak of the Western Ghats of India. Current Science, 98: 1119-1125.

Blyth, E. (1852). Report of curator, zoological department. The Journal of the Asiatic Society of Bengal, 21: 341-358.

Bogart, J. P. (1981). How many times has terrestrial breeding evolved in anuran amphibians? Monitore Zoologico Italiano-Italian Journal of Zoology, 15 (3): 29-40. https://doi.org/10.1080/03749444.1981.10736627

Bogert, C. M. and Senanayake, R. (1966). A new species of toad (Bufo) indigenous to southern Ceylon. American Museum Novitates, 2269: 1-18.

Bolkay, S. J. (1915). Beiträge zur Osteologie einiger exotischer Raniden. Anatomischer Anzeiger, Jena, 48: 172-183. https://doi.org/10.5962/bhl.part.17101

Bopage, M. M., Wewalwala, K., Krvavac, M., Jovanovic, O., Safarek, G. and Pushpamal, V. (2011). Species diversity and threat status of amphibians in the Kanneliya Forest, lowland Sri Lanka. Salamandra, 47 (3): 173-177.

Bossuyt, F. and Dubois, A. (2001). A review of the frog genus Philautus Gistel, 1848 (Amphibia, Anura, Ranidae, Rhacophorinae). Zeylanica, 6 (1): 1-112.

Bossuyt, F., Meegaskumbura, M., Beenaerts, N., Gower, D. J., Pethiyagoda, R., Roelants, K., Mannaert, A., Wilkinson, M., Bahir, M. M., Manamendra-Arachchi, K., Ng, P. K. L., Schneider, C. J., Oommen, O. V. and Milinkovitch, M. C. (2004). Local endemism within the Western Ghats-Sri Lanka biodiversity hotspot. Science, 306 (5695): 479-481. https://doi.org/10.1126/science.1100167

Boulenger, G. A. (1882a). Catalogue of the Batrachia Salientia s. Ecaudata in the collection of the British Museum. Second Edition. Taylor and Francis, London. xvi+503 pp. https://doi.org/10.5962/bhl.title.12075

Boulenger, G. A. (1882b). Description of a new genus and species of frogs of the family Ranidae. Annals and Magazine of Natural History, Series 5, 10 (55): 35. https://doi.org/10.1080/00222938209459662

Boulenger, G. A. (1904). Descriptions of three new frogs from southern India and Ceylon. Journal of the Bombay Natural History Society, 15: 430-431.

Boulenger, G. A. (1905) [1904]. Description of a frog from Ceylon, hitherto confounded with Rana limnocharis. Spolia Zeylanica, 2: 73-74.

Brook, B. W., Sodhi, N. S. and Ng, P. K. L. (2003). Catastrophic extinctions follow deforestation in Singapore. Nature, 424: 420-423. https://doi.org/10.1038/nature01795

Caorsi, V. Z., Both, C., Cechin, S., Antunes, R. and Borges-Martins, M. (2017). Effects of traffic noise on the calling behavior of two Neotropical hylid frogs. PLOS ONE, 12 (8): e0183342. https://doi.org/10.1371/journal.pone.0183342

Chandramouli, S. R., Ankaiah, D., Arul, V., Dutta, S. K. and Ganesh, S. R. (2019). On the taxonomic status of Minervarya granosa (Kuramoto, Joshy, Kurabayashi and Sumida, 
2008) and the distribution of M. agricola (Jerdon, 1853) Amphibia: Anura: Dicroglossidae. Asian Journal of Conservation Biology, 8 (1): 84-87.

Clarke, B. T. (1983). A morphological re-examination of the frog genus Nannophrys (Anura: Ranidae) with comments on its biology, distribution and relationships. Zoological Journal of the Linnean Society, 79 (4): 377-398. https://doi.org/10.1111/j.10963642.1983.tb01171.x

Cope, E. D. (1861) [1860]. Descriptions of reptiles from tropical America and Asia. Proceedings of the Academy of Natural Sciences of Philadelphia, 12: 368-374.

Dahanukar, N., Sulakhe, S. and Padhye, A. (2017). Identity of Sphaerotheca pluvialis (Jerdon, 1853 ) and other available names among the burrowing frogs (Anura: Dicroglossidae) of South Asia. Journal of Threatened Taxa, 9 (6): 10269-10285. http://doi.org/10.11609/jott.3358.9.6.10269-10285

De Benedictis, P. A. (1974). Interspecific competition between tadpoles of Rana pipiens and Rana sylvatica: an experimental field study. Ecological Monographs, 44 (2): 129-151. https://doi.org/10.2307/1942308

De Costa, W. A. J. M. (2008). Climate change in Sri Lanka: myth or reality? Evidence from long-term meteorological data. Journal of the National Science Foundation of Sri Lanka, 36: 63-88. https://jnsfsl.sljol.info/articles/abstract/10.4038/jnsfsr.v36i0.8048/

De Silva, A. (1995). The Amphibia of Sri Lanka: a provisional checklist and their common names. Lyriocephalus, 1: 20-26.

De Silva, A. (1996). The Amphibia of Sri Lanka: a checklist and an annotated bibliography. Department of Wildlife Conservation/GEF/UNDP/FAO, Colombo, Sri Lanka. 48 pp.

De Silva, A. (2011). Some observations of malformation, eye disease, parasitic and viral infection and the effects of agrochemicals on amphibians in Sri Lanka. FrogLog, 98: 2425.26 .

De Silva, M. (2006). An experimental phytotelm Conservation project for a microhylid frog Ramanella nagaoi. Loris, 24: 15-19.

De Silva, S. and Wijayathilaka N. (2019). Bioacoustics of Sri Lankan amphibians: a review of current knowledge and conservation significance. Journal of Tropical Forestry and Environment, 9 (1): 1-6. https://doi.org/10.31357/jtfe.v9i1.3944

Dinesh, K. P., Radhakrishnan, C., Channakeshavamurthy, B. H. and Kulkarni, N. U. (2015). Checklist of Amphibia of India, updated till January 2015 available at http://mhadeiresearchcenter.org/resources (Accessed 22.12.2016).

Dubois, A. (1983). Note préliminaire sur le groupe de Rana (Tomopterna) breviceps Schneider, 1799 (Amphibiens, Anoures), avec diagnose d'une sous-expèce nouvelle de Ceylan. Alytes, 2 (4): 163-170.

Dubois, A. and Ohler, A. (2001). A new genus for an aquatic ranid (Amphibia, Anura) from Sri Lanka. Alytes, 19 (2-4): 81-106.

Duméril, A. M. C. and Bibron, G. (1841). Erpétologie Genérale ou Histoire Naturelle Complète des Reptiles. Volume 8. Librarie Enclyclopedique de Roret, Paris. 792 pp. https://doi.org/10.5962/bhl.title.45973

Dutta, S. K. (1997). Amphibians of India and Sri Lanka (Checklist and Bibliography). Odyssey Publishing House, Orissa. xiii+342+xxii pp.

Dutta, S. K. and Manamendra-Arachchi, K. (1996). The Amphibian fauna of Sri Lanka. Wildlife Heritage Trust of Sri Lanka, Colombo, Sri Lanka. 232 pp. 
Fernando, P. and Siriwardhane, M. (1996). Microhyla karunaratnei (Anura: Microhylidae), a new species of frog endemic to Sri Lanka. Journal of South Asian Natural History, 2 (1): $135-142$.

Fernando, P., Dayawansa, N. and Siriwardhane, M. (1994). Bufo kotagamai, a new toad (Bufonidae) from Sri Lanka. Journal of South Asian Natural History, 1 (1): 119-124.

Fernando, S. S., Wickramasingha, L. J. M. and Rodirigo, R. K. (2007). A new species of endemic frog belonging to genus Nannophrys Günther, 1869 (Anura: Dicroglossinae) from Sri Lanka. Zootaxa, 1403 (1): 55-68. http://dx.doi.org/10.11646/zootaxa.1403.1.3

Ferraz, G., Russell, G. J., Stouffer, P. C., Bierregaard, R. O., Pimm, S. L. and Lovejoy, T. E. (2003). Rates of species loss from Amazonian forest fragments. PNAS, 100 (24): 1406914073. https://doi.org/10.1073/pnas.2336195100

Fitzinger, L. J. F. J. (1826). Neue Classification der Reptilien nach ihren Natürlichen Verwandtschaften nebst einer Verwandtschafts-Tafel und einem Verzeichnisse der Reptilien-Sammlung des K. K. Zoologisch Museum's zu Wien. J. G. Heubner, Wien. 66 pp. https://doi.org/10.5962/bhl.title.4683

Fitzinger, L. J. F. J. (1843). Systema Reptilium. Fasciculus Primus. Braumüller ET Seidel, Wien. 106 pp. https://doi.org/10.5962/bhl.title.4694

Frost, D. R. (2018). Amphibian Species of the World: an Online Reference. Version 6.0. http://research.amnh.org/herpetology/amphibia/index.html. American Museum of Natural History, New York, USA (Accessed 21.09.2018).

Frost, D. R., Grant, T., Faivovich, J., Bain, R. H., Haas, A., Haddad, C. F. B., De Sá, R. O., Channing, A., Wilkinson, M., Donnellan, S. C., Raxworthy, C. J., Campbell, J. A., Blotto, B. L., Moler, P., Drewes, R. C., Nussbaum, R. A., Lynch, J. D., Green, D. M. and Wheeler, W. C. (2006). The amphibian tree of life. Bulletin of the American Museum of Natural History, 297: 1-370. http://digitallibrary.amnh.org/dspace/handle/2246/5781 (Accessed 2 December 2018).

Garg, S., Senevirathne, G., Wijayathilaka, N., Phuge, S., Deuti, K., Manamendra-Arachchi, K., Meegaskumbura, M. and Biju, S. D. (2018). An integrative taxonomic review of the South Asian microhylid genus Uperodon. Zootaxa, 4384 (1): 1-88. https://doi.org/10.11646/zootaxa.4384.1.1

Gosz, J. R. (1993). Ecotone hierarchies. Ecological Applications, 3 (3): 369-376. https://doi.org/10.2307/1941905

Gower, D. J., Bahir, M. M., Mapatuna, Y., Pethiyagoda, R., Raheem, D. and Wilkinson, M. (2005). Molecular phylogenetics of Sri Lankan Ichthyophis (Amphibia: Gymnophiona: Ichthyophiidae), with discovery of a cryptic species. The Raffles Bulletin of Zoology, 12: $153-161$.

Gravenhorst, J. L. C. (1829). Deliciae Musei Zoologici Vratislaviensis. Fasciculus primus. Chelonios ET Batrachia. Leopold Voss, Leipzig. 106 pp.

Gray, J. E. (1825). A synopsis of the genera of reptiles and amphibia, with a description of some new species. Annals of Philosophy, New Series, 10: 193-217.

Gray, J. E. (1834). Illustrations of Indian Zoology; chiefly selected from the Collection of Major-General Hardwicke, F. R. S. Volume 1. Part 3. Treuttel, Wurtz, Treuttel, Jun. and Richter, London. 100 pls. https://doi.org/10.5962/bhl.title.95127

Gunatilleke, I. A. U. N., Gunatilleke, C. V. S. and Dilhan, M. A. A. B. (2005). Plant biogeography and conservation of the south-western hill forests of Sri Lanka. The Raffles Bulletin of Zoology, 12: 9-22. 
Günther, A. C. L. G. (1858). Neue Batrachier in der Sammlung des britischen Museums. Archiv für Naturgeschichte Berlin, 24: 319-328. https://doi.org/10.5962/bhl.part.5288

Günther, A. C. L. G. (1859) [1858]. Catalogue of the Batrachia Salientia in the Collection of the British Museum. London: Taylor and Francis. xvi+160 pp. https://doi.org/10.5962/bhl.title.20903

Günther, A. C. L. G. (1864). The reptiles of British India. London, Ray Society. xxvii+452 pp. https://doi.org/10.5962/bhl.title.5012

Günther, A. C. L. G. (1869) [1868]. First account of species of tailless batrachians added to the collection of the British Museum. Proceedings of the Zoological Society of London, 1868: 478-490.

Günther, A. C. L. G. (1872). Descriptions of some Ceylonese reptiles and batrachians. Annals and Magazine of Natural History, (4) 9: 85-88.

Günther, A. C. L. G. (1876a) [1875]. Third report on collections of Indian reptiles obtained by the British Museum. Proceedings of the Zoological Society of London, 1875: 567-577.

Günther, A. C. L. G. (1876b). Notes on the mode of propagation of some Ceylonese treefrogs, with description of two new species. Annals and Magazine of Natural History, (4) 17: $377-380$.

Gurushankara, H. P., Krishnamurthy, S. V. and Vasudev, V. (2007). Morphological abnormalities in natural populations of common frogs inhabiting agroecosystems of central Western Ghats. Applied Herpetology, 4 (1): 39-45. https://doi.org/10.1163/157075407779766651

Hu, J., Li, C., Xie, F. and Jiang, J. (2012). Endemic amphibians and their distribution in China. Asian Herpetological Research, 3 (2): 163-171. https://doi.org/10.3724/SP.J.1245.2012.00163

Inger, R. F. (1972). Bufo of Eurasia. In: Blair, W.F. (Ed.), Evolution in the genus Bufo. University of Texas Press, Austin. pp. 102-118.

IUCN (International Union for Conservation of Nature) Sri Lanka (1999). The 1999 Red List of Threatened Fauna and Flora of Sri Lanka. IUCN Sri Lanka, Colombo. 113 pp.

IUCN Sri Lanka (2007). The Fauna of Sri Lanka (Status of taxonomy, research and conservation). IUCN Sri Lanka, Colombo. 148 pp.

IUCN Sri Lanka (2012). The Fauna of Sri Lanka (Status of taxonomy, research and conservation). IUCN Sri Lanka, Colombo. 452 pp.

Janzen, P. and Bopage, M. (2011). The herpetofauna of a small and unprotected patch of tropical rainforest in Morningside, Sri Lanka. Amphibian and Reptile Conservation, 5 (2): $1-13$.

Jayawardena, B., Senevirathne, G., Wijayathilaka, N., Ukuwela, K., Manamendra-Arachchi, K. and Meegaskumbura, M. (2017). Species boundaries, biogeography and evolutionarily significant units in dwarf toads: Duttaphrynus scaber and D. atukoralei (Bufonidae: Adenominae). Ceylon Journal of Science, 46: 79-87. http://doi.org/ 10.4038/cjs.v46i5.7455

Jerdon, T. C. (1853). Catalogue of reptiles inhabiting the Peninsula of India. The Journal of the Asiatic Society of Bengal, 22: 522-534.

Johnson, P. T. J., Chase, J. M., Dosch, K. L., Hartson, R. B., Gross, J. A., Larson, D. J., Sutherland, D. R. and Carpenter, S. R. (2007). Aquatic eutrophication promotes pathogenic infection in amphibians. PNAS, 104 (40): 15781-15786. https://doi.org/10.1073/pnas.0707763104 
Joshy, S. H., Alam, M. S., Kurabayashi, A., Sumida, M. and Kuramoto, M. (2009). Two new species of the genus Euphlyctis (Anura, Ranidae) from southwestern India, revealed by molecular and morphological comparisons. Alytes, 26 (1-4): 97-116.

Kaiser, K. and Hammers, J. L. (2009). The effect of anthropogenic noise on male advertisement call rate in the Neotropical treefrog, Dendropsophus triangulum. Behaviour, 146 (8): 1053-1069.

Kaiser, K., Scofield, D. G., Alloush, M., Jones, R. M., Marczak, S., Martineau, K., Oliva, M. A. and Narins, P. M. (2011). When sounds collide: the effect of anthropogenic noise on a breeding assemblage of frogs in Belize, Central America. Behaviour, 148 (2): 215-232. https://doi.org/10.1163/000579510X551660

Kandamby, D. S. (2001). Some amphibians observed in Galle District, Sri Lanka. Lyriocephalus, 4: 89-92.

Kandamby, D. S. and Batuwita, S. (2001). Some observations on the distribution of Rhacophorus cavirostris (Gunther, 1868) endemic tree frog from Sri Lanka. Lyriocephalus, 4: 93-94.

Kark, S. and van Rensburg, B. J. (2006). Ecotones: Marginal or central areas of transition? Journal of Ecology and Evolution, 52 (1): 29-53. https://doi.org/10.1560/IJEE.52.1.29

Karunarathna, D. M. S. S., Abeywardena, U. T. I., Asela, M. D. C. and Kekulandala, L. D. C. B. (2008). A preliminary survey of the amphibian fauna in Nilgala Forest area and its vicinity, Monaragala District, Sri Lanka. Herpetological Conservation and Biology, 3 (2): 264-272.

Karunarathna, S., Bauer, A. M., De Silva, A., Surasinghe, T., Somaratna, L., Madawala, M., Gabadage, D., Botejue, M., Henkanaththegedara, S. and Ukuwela, K. D. B. (2019a). Description of a new species of the genus Cnemaspis Strauch, 1887 (Reptilia: Squamata: Gekkonidae) from the Nilgala Savannah forest, Uva Province of Sri Lanka. Zootaxa, 4545 (3): 389-407. https://doi.org/10.11646/zootaxa.4545.3.4

Karunarathna, S., Poyarkov, N. A., De Silva, A., Madawala, M., Botejue, M., Gorin, V. A., Surasinghe, T., Gabadage, D., Ukuwela, K. D. B. and Bauer, A. M. (2019b). Integrative taxonomy reveals six new species of day geckos of the genus Cnemaspis Strauch, 1887 (Reptilia: Squamata: Gekkonidae) from geographically-isolated hill forests in Sri Lanka. Vertebrate Zoology, 69(3): 247-298. http://doi.org/10.26049/VZ69-3-2019-02

Karunarathna, S., Ranwala, S., Surasinghe, T. and Madawala, M. (2017). Impact of vehicular traffic on vertebrate fauna in Horton Plains and Yala national parks of Sri Lanka: some implications for conservation and management. Journal of Threatened Taxa, 9 (3): 9928-9939. http://doi.org/10.11609/jott.2715.93.9928-9939

Karunarathna, S., Henkanaththegedara, S., Gabadage, D., Botejue, M., Madawala, M. and Surasinghe, T. D. (2016). Ecology and demography of the critically endangered Kandian torrent toad Adenomus kandianus: a long-lost endemic species of Sri Lanka. Oryx, 51 (4): 619-626. https://doi.org/10.1017/S0030605316000594

Kelaart, E. F. (1853). Prodromus faunae zeylanicae; being contributions to the zoology of Ceylon. Published by the author, Colombo, Sri Lanka. vii+xxxiii+197+62+iv pp.

Kelaart, E. F. (1854). Prodromus faunae zeylanicae; being contributions to the zoology of Ceylon. Government Press, Colombo, Sri Lanka. 23+31+xvi pp. https://doi.org/10.5962/bhl.title.123402

Khajeh, A., Mohammadi, Z., Ghorbani, F., Meshkani, J., Rastegar-Pouyani, E. and Torkamanzehi, A. (2014). New insights into the taxonomy of the skittering frog Euphlyctis cyanophlyctis complex (Schneider, 1799) (Amphibia: Dicroglossidae) based 
on mitochondrial 16S rRNA gene sequences in southern Asia. Acta Herpetologica, 9 (2): 159-166. https://doi.org/10.13128/Acta_Herpetol-14013

Kirtisinghe, P. (1946). The genus Nannophrys Günther (Amphibia, Ranidae) with the description of a new species. Ceylon Journal of Science. Section B, Zoology, 23: 105107.

Kirtisinghe, P. (1957). The Amphibia of Ceylon. Published by the author, Colombo, Sri Lanka. xiii+112 pp.

Kotagama, S. W., Arudpragasam, K. D. and Kotalawala, I. (1981). A check list of Amphibia of Sri Lanka. National Science Council (National Science Foundation), Colombo, Sri Lanka. 8 pp.

Kottawa-Arachchi, J. D. and Wijeratne, M. A. (2017). Climate change impacts on biodiversity and ecosystems in Sri Lanka: a review. Nature Conservation Research, 2 (3): 2-22. https://doi.org/10.24189/ncr.2017.042

Kuhl, H. and Van Hasselt, J. C. (1822). Uittreksels uit brieven van de Heeren Kuhl en Van Hasselt, aan de Heeren C. J. Temminck, Th. Van Swinderen en W. De Haan. Algemeene Konst- en LetterBode, 7: 99-104.

Laurent, R. F. (1943). Contribution a l'osteologie et a la systematique des rhacophorides non Africains. Bulletin du Musée Royal d'Histoire Naturelle de Belgique, 19: 1-16.

Legg, C. and Jewell, N. (1995). A 1:50,000-scale forest map of Sri Lanka: the basis for a national forest geographic information system. Sri Lanka Forester, 20 (3, 4): 35-44.

Lesson, R.-P. (1834). Reptiles. In: Bélanger, C. (ed.), Voyage aux Indes-Orientales, par le nord de l'Europe, les provinces du Caucase, la Géorgie, l'Arménie et la Perse, suivi de details topographiques, statistiques et autres sur le Pégou, les Isles de Java, de Maurice et de Bourbon, sur le Cap-de-bonne-Espérance et Sainte-Hélène, pendant ... 1825-29. Zoologie (Texte) [Octavo] and Atlas [Quarto], Paris, Arthus Bertrand, 291-336 pp.

Li, J. T., Li, Y., Klaus, S., Rao, D. Q., Hillis, D. M. and Zhang, Y. P. (2013). Diversification of rhacophorid frogs provides evidence for accelerated faunal exchange between India and Eurasia during the Oligocene. PNAS, 110 (9): 3441-3446. https://doi.org/10.1073/pnas.1300881110

Lichtenstein, H. and Martens, E. (1856). Nomenclator Reptilium et Amphibiorum Musei Zoologici Berolinensis. Namenverziechniss der in der zoologischen Sammlung der Königlichen Universität zu Berlin aufgestellten Arten von Reptilien und Amphibien nach ihren Ordnungen, Familien und Gattungen. Berlin. iv+48 pp.

Linnaeus, C. (1758). Systema Naturae per Regna Tria Naturae, Secundum Classes, Ordines, Genera, Species, cum Characteribus, Differentiis, Synonymis, Locis. 10th Edition. Volume 1. L. Salvii, Stockholm. 775 pp. https://doi.org/10.5962/bhl.title.37256

Lütken, C. F. (1864) [1863]. Nogle ny Krybyr og Padder. Videnskabelige Meddelelser fra Dansk Naturhistorisk Forening i Kjøbenhavn, (2)4: 292-311.

Maduwage, K. P., Silva, A. and Batuwita, S. (2003). Snakes killed on the Roads of the Gardens of University of Peradeniya. Loris, 23: 22-24.

Manamendra-Arachchi, K. and Gabadage, D. E. (1996). Limnonectes kirtisinghei, a new species of ranid frog from Sri Lanka. Journal of South Asian Natural History, 2: 31-42.

Manamendra-Arachchi, K. and Pethiyagoda, P. (1998). A synopsis of the Sri Lankan Bufonidae (Amphibia: Anura) with description of new species. Journal of South Asian Natural History, 3: 213-248. 
Manamendra-Arachchi, K. and Pethiyagoda, R. (2001a). Ramanella nagaoi, a new tree-hole frog (Microhylidae) from southern Sri Lanka. Journal of South Asian Natural History, 5: 121-133.

Manamendra-Arachchi, K. and Pethiyagoda, R. (2001b). Polypedates fastigo, a new tree frog (Ranidae: Rhacophorinae) from Sri Lanka. Journal of South Asian Natural History, 5: 191-199.

Manamendra-Arachchi, K. and Pethiyagoda, R. (2005). The Sri Lankan shrub-frogs of the genus Philautus Gistel, 1848 (Ranidae: Rhacophorinae), with description of 27 new species. The Raffles Bulletin of Zoology, 12: 163-303.

Manamendra-Arachchi, K. and Pethiyagoda, R. (2006). Amphibians of Sri Lanka (in Sinhala). Wildlife Heritage Trust of Sri Lanka, Colombo, Sri Lanka. 440 pp.

Meegaskumbura, M. and Manamendra-Arachchi, K. (2005). Descriptions of eight new species of shrub frogs (Ranidae: Rhacophorinae: Philautus) from Sri Lanka. The Raffles Bulletin of Zoology, 12: 305-338.

Meegaskumbura, M. and Manamendra-Arachchi, K. (2011). Two new species of shrub frogs (Rhacophoridae: Pseudophilautus) from Sri Lanka. Zootaxa, 2747 (1): 1-18. http://dx.doi.org/10.11646/zootaxa.2747.1.1

Meegaskumbura, M., Bossuyt, F., Pethiyagoda, R., Manamendra-Arachchi, K., Bahir, M. M., Milinkovitch, M. C. and Schneider, C. J. (2002). Sri Lanka: an amphibian hotspot. Science, 298: 379. https://doi.org/10.1126/science.298.5592.379

Meegaskumbura, M., Manamendra-Arachchi, K. and Pethiyagoda, R. (2009). Two new species of shrub frogs (Rhacophoridae: Philautus) from the lowlands of Sri Lanka. Zootaxa, 2122 (1): 51-68. http://dx.doi.org/10.11646/zootaxa.2747.1.1

Meegaskumbura, M., Manamendra-Arachchi, K., Bowatte, G. and Meegaskumbura, S. (2012a). Rediscovery of Pseudophilautus semiruber, a diminutive shrub frog (Rhacophoridae: Pseudophilautus) from Sri Lanka. Zootaxa, 3229 (1): 58-68. http://dx.doi.org/10.11646/zootaxa.3229.1.4

Meegaskumbura, M., Meegaskumbura, S., Gunatilleke, N., Manamendra-Arachchi, K., Bowatte, G., Gunatilleke, T. and Bandara, C. (2012b). Conservation and biogeography of threatened Amphibians of Eastern Sinharaja. FrogLog, 100: 12-14.

Meegaskumbura, M., Meegaskumbura, S., Bowatte, G., Manamendra-Arachchi, K., Pethiyagoda, R., Hanken, J. and Schneider, C. J. (2010). Taruga (Anura: Rhacophoridae), a new genus of foam-nesting tree frogs endemic to Sri Lanka. Ceylon Journal of Science (Biological Sciences), 39 (2): 75-94. http://doi.org/10.4038/cjsbs.v39i2.2995

Meegaskumbura, M., Manamendra-Arachchi, K., Schneider, C. J. and Pethiyagoda, R. (2007). New species amongst Sri Lanka's extinct shrub frogs (Amphibia: Rhacophoridae: Philautus). Zootaxa, 1397 (1): 1-15. http://dx.doi.org/ 10.11646/zootaxa.1397.1.1

Meegaskumbura, M., Seneviratne, G., Wijayathilaka, N., Jayawardena, B., Bandara, C., Manamendra-Arachchi, K. and Pethiyagoda, R. (2015). The Sri Lankan torrent toads (Bufonidae: Adenominae: Adenomus): species boundaries assessed using multiple criteria. Zootaxa, 3911 (2): 245-261. http://dx.doi.org/10.11646/zootaxa.3911.2.6

Meegaskumbura, M., Seneviratne, G., Manamendra-Arachchi, K., Pethiyagoda, R., Hanken, J. and Schneider, C. J. (2019). Diversification of shrub frogs (Rhacophoridae, Pseudophilautus) in Sri Lanka-Timing and geographic context. Molecular Phylogenetics and Evolution, 132: 14-24. https://doi.org/10.1016/j.ympev.2018.11.004

Méhely, L. (1897). Zur Herpetologie von Ceylon. Természetrajzi Füzetek, 20: 55-70. 
Min, M. S., Lee, H. and Waldman, B. (2011). Amphibian Population Declines and Chytridiomycosis in South Korea. FrogLog, 98: 12-13.

Mittermeier, R. A., Myers, N., Thomsen, J. B., Da Fonseca, G. A. B. and Olivieri, S. (1998). Biodiversity hotspots and major tropical wilderness areas: approaches to setting conservation priorities. Conservation Biology, 12 (3): 516-520. https://doi.org/10.1046/j.1523-1739.1998.012003516.x

Müller, F. (1887). Fünfter Nachtrag zum Katalog der herpetologischen Sammlung des Basler Museum. Verhandlungen der Naturforschenden Gesellschaft in Basel, 8: 249-296.

Myers, N., Mittermeier, R. A., Mittermeier, C. G., da Fonseca, G. A. B. and Kent, J. (2000). Biodiversity hotspots for conservation priorities. Nature, 403: 853-858. https://doi.org/10.1038/35002501

Naniwadekar, R. and Vasudevan, K. (2007). Patterns in diversity of anurans along an elevational gradient in the Western Ghats, South India. Journal of Biogeography, 34 (5): 842-853. https://doi.org/10.1111/j.1365-2699.2006.01648.x

Nguyen, T. T., Nguyen, T. V., Ziegler, T., Pasmans, F. and Martel, A. (2017). Trade in wild anurans vectors the urodelan pathogen Batrachochytrium salamandrivorans into Europe. Amphibia-Reptilia, 38 (4): 554-556. https://doi.org/10.1163/15685381-00003125

Nishikawa, K., Matsui, M., Yong, H.-S., Ahmad, N., Yambun, P., Belabut, D. M., Sudin, A., Hamidy, A., Orlov, N. L., Ota, H., Yoshikawa, N., Tominaga, A. and Shimada, T. (2012). Molecular phylogeny and biogeography of caecilians from Southeast Asia (Amphibia, Gymnophiona, Ichthyophiidae), with special reference to high cryptic species diversity in Sundaland. Molecular Phylogenetics and Evolution, 63 (3): 714-723. https://doi.org/10.1016/j.ympev.2012.02.017

Nussbaum, R. A. and Gans, C. (1980). On the Ichthyophis (Amphibia: Gymnophiona) of Sri Lanka. Spolia Zaylanica, 35 (1, 2): 137-154.

Odum, E. P. (1953). Fundamentals of Ecology. First Edition. W. B. Saunders Company, Philadelphia. Xii + 384 pp.

Parker, H. W. (1934). A monograph of the frogs of the family Microhylidae. The British Museum (Natural History), London. 208 pp.

Parker, H. W. and Osman Hill, W. C. (1948). Frogs of the genus Microhyla from Ceylon. Annals and Magazine of Natural History, 1 (10): 759-764. https://doi.org/10.1080/00222934808653944

Peabotuwage, I., Bandara, I. N., Samarasinghe, D., Perera, N., Madawala, M., Amarasinghe, C., Kandambi, H. K. D. and Karunarathna, D. M. S. S. (2012). Range extension for Duttaphrynus kotagamai (Amphibia: Bufonidae) and a preliminary checklist of herpetofauna from the Uda Maliboda Trail in Samanala Nature Reserve, Sri Lanka. Amphibian and Reptile Conservation, 5 (2): 52-64.

Peloso, P. L. V., Frost, D. R., Richards, S. J., Rodrigues, M. T., Donnellan, S., Matsui, M., Raxworthy, C. J., Biju, S. D., Lemmon, E. M., Lemmon, A. R. and Wheeler, W. C. (2016). The impact of anchored phylogenomics and taxon sampling on phylogenetic inference in narrow-mouthed frogs (Anura, Microhylidae). Cladistics, 32 (2): 113-140. https://doi.org/10.1111/cla.12118

Perl, R. G. B., Geffen, E., Malka, Y., Barocas, A., Renan, S., Vences, M. and Gafny, S. (2018). Population genetic analysis of the recently rediscovered Hula painted frog (Latonia nigriventer) reveals high genetic diversity and low inbreeding. Scientific Reports, 8: 5588. https://doi.org/10.1038/s41598-018-23587-w 
Peters, W. C. H. (1863). Über eine neue Schlangen-gattung, Styporhynchus, und verschiedene andere Amphibien des zoologischen Museum. Monatsberichte der Königlichen Preussische Akademie des Wissenschaften zu Berlin, 1863: 399-413.

Pethiyagoda, R. (1991). Freshwater fishes of Sri Lanka. Wildlife Heritage Trust of Sri Lanka, Colombo, Sri Lanka. 362 pp.

Pethiyagoda, R. and Manamendra-Arachchi, K. (1998). Evaluating Sri Lanka's amphibian diversity. Occassional Papers of the Wildlife Heritage Trust, 2: 1-12.

Pounds, J. A. and Puschendorf, R. (2004). Clouded futures. Nature, 427: 107-109. https://doi.org/10.1038/427107a

Rajapakshe, R. V. P. J. and De Silva, A. (2001). Preliminary observations of the parasites of amphibian fauna at Horton Plains National Park. Lyriocephalus, 4: 166-167.

Risser, P. G. (1995). The status of the science examining ecotones: a dynamic aspect of landscape is the area of steep gradients between more homogeneous vegetation associations. BioScience, 45 (5): 318-325. https://doi.org/10.2307/1312492

Ryan, M. J., Scott, N. J., Cook, J. A., Willink, B., Chaves, G., Bolãnos, F., García-Rodríguez, A., Latella, I. M. and Koerner, S. E. (2015). Too wet for frogs: changes in a tropical leaf litter community coincide with La Niña. Ecosphere, 6 (1): 1-10. http://dx.doi.org/10.1890/ES14-00352.1

Sanchez, E., Biju, S. D., Islam, M. M., Hasan, M., Ohler, A., Vences, M. and Kurabayashi, A. (2018). Phylogeny and classification of fejervaryan frogs (Anura: Dicroglossidae). Salamandra, 54 (2): 109-116.

Schilthuizen, M. (2000). Ecotone: Speciation-prone. Trends in Ecology and Evolution, 15 (4): 130-131. https://doi.org/10.1016/S0169-5347(00)01839-5

Schneider, J. G. (1799). Historia Amphibiorum Naturalis et Literarariae. Fasciculus Primus. Continens Ranas, Calamitas, Bufones, Salamandras et Hydros in Genera et Species Descriptos Notisque suis Distinctos. Friederici Frommanni, Jena. 302 pp.

Seale, D. B. (1980). Influence of amphibian larvae on primary production, nutrient flux, and competition in a pond ecosystem. Ecology, 61 (6): 1531-1550. https://doi.org/10.2307/1939059

Seba, A. (1735). Locupletissimi rerum naturalium thesauri accurata descriptio, et iconibus artificiosissimis expressio, per universam physices historiam: Opus, cui, in hoc rerum genere, nullum par exstitit. Ex toto terrarum orbe collegit, digessit, et depingendum curavit. Volume II. Wetstenium, Smith and Janssonio-Waesbergios, Amsterdam. 132+1-154 pp., 114 pls. https://doi.org/10.5962/bhl.title.62760

Senanayake, F. R., Soulè, M. and Senner, J. W. (1977). Habitat values and endemicity in the vanishing rains forests of Sri Lanka. Nature, 265: 351-354. https://doi.org/10.1038/265351a0

Senevirathne, G., Samarawickrama, V. A. M. P. K., Wijayathilaka, N., ManamendraArachchi, K., Bowatte, G., Samarawickrama, D. R. N. S. and Meegaskumbura, M. (2018). A new frog species from rapidly dwindling cloud forest streams of Sri LankaLankanectes pera (Anura, Nyctibatrachidae). Zootaxa, 4461 (4): 519-538. http://dx.doi.org/10.11646/zootaxa.4461.4.4

Shaw, G. (1802). General Zoology or Systematic Natural History. Volume III, Part 1. Amphibia. Thomas Davison, London. 312 pp.

Seymour, R. S. (1999). Respiration of aquatic and terrestrial amphibian embryos. American Zoologist, 39 (2): 261-270. www.jstor.org/stable/3884249 
Shreve, B. (1940). A new Rhacophorus and a new Philautus from Ceylon. Proceedings of the Biological Society of Washington, 53: 105-108.

Silva, P. and Kurukulasuriya, M. (2010). Invasive alien fauna in Sri Lanka - Introduction, spread, impacts and management, In: Marambe, B., Silva, P., Wijesundara, S. and Atapattu, N. (Eds.), Invasive Alien Species in Sri Lanka- strengthening capacity to control their introduction and spread. Biodiversity Secretariat of the Ministry of Environment, Colombo, Sri Lanka. pp. 39-61.

Sredl, M. J. and Collins, J. P. (1992). The interaction of predation, competition, and habitat complexity in structuring an amphibian community. Copeia, 1992 (3): 607-614.

Stuart, S. N., Chanson, J. S., Cox, N. A., Young, B. E., Rodrigues, A. S. L., Fischman, D. L. and Waller, R.W. (2004). Status and trends of amphibian declines and extinctions worldwide. Science, 306 (5702): 1783-1786. http://dx.doi.org/10.1126/science.1103538

Sun, J. W. C. and Narins, P. M. (2005). Anthropogenic sounds differentially affect amphibian call rate. Biological Conservation, 121 (3): 419-427. https://doi.org/ 10.1016/j.biocon.2004.05.017

Surasinghe, T. D. (2009). Conservation and distribution status of amphibian fauna in Sri Lanka. Biodiversity, 10 (1): 3-17. https://doi.org/10.1080/14888386.2009.9712632

Taigen, T. L., Pough, F. H. and Stewart, M. M. (1984). Water balance of terrestrial anuran (Eleutherodactylus coqui) eggs: importance of parental care. Ecology, 65 (1): 248-255. https://doi.org/10.2307/1939477

Taylor, B., Skelly, D., Demarchis, L. K., Slade, M. D., Galusha, D. and Rabinowitz, P. M. (2005). Proximity to pollution sources and risk of amphibian limb malformation. Environmental Health Perspectives, $113 \quad$ (11): $1497-1501$. https://doi.org/10.1289/ehp.7585

Taylor, E. H. (1965). New Asiatic and African caecilians with redescriptions of certain other species. The University of Kansas Science Bulletin, 46 (6): 253-302. https://doi.org/10.5962/bhl.part.20077

Taylor, E. H. (1969). Miscellaneous notes and descriptions of new forms of caecilians. The University of Kansas Science Bulletin, 48 (9): 281-296. https://doi.org/10.5962/bhl.part.11223

Tschudi, J. J. (1838). Classification der Batrachier, mit Berucksichtigung der fossilen Thiere dieser Abtheilung der Reptilien. Neuchatel, Petitpierre. ii+99 pp., 6 pls. https://doi.org/10.5962/bhl.title.4883

UNESCO (United Nations Educational, Scientific and Cultural Organization) (2010). UNESCO Headquarters, 7, Place de Fontenoy, 75352, Paris, 07 SP, France. http://whc.unesco.org/en/list/1203/documents (Accessed 17 November 2019).

Van Bocxlaer, I., Biju, S. D., Loader, S. P. and Bossuyt, F. (2009). Toad radiation reveals into-India dispersal as a source of endemism in the Western Ghats-Sri Lanka biodiversity hotspot. BMC Evolutionary Biology, 9, 131: 1-10. https://doi.org/10.1186/1471-2148-9131

WCSG (Wildlife Conservation Society-Galle) (2008). The study of the faunal diversity in Galle District- Southern, Sri Lanka. Galle, Wildlife Conservation Society- Galle, Sri Lanka. 44 pp.

WCSG (Wildlife Conservation Society-Galle) (2009). The study of the faunal diversity in Matara District-Southern, Sri Lanka. Wildlife Conservation Society- Galle, Sri Lanka. 43 pp. 
Weerawardhena, S. R. and Russell, A. (2012). Cover-dependency of anurans in the Riverstone, Knuckles mountain forest range, Sri Lanka. Taprobanica, 4 (1): 12-19.

Werner, W. L. (1988). Canopy dieback in the upper montane rain forests of Sri Lanka. GeoJournal, 17: 245-248. https://doi.org/10.1007/BF02432929

Wickramasinghe, L. J. M. and Munindradasa, D. A. I. (2007). Review of the genus Cnemaspis Strauch, 1887 (Sauria: Gekkonidae) in Sri Lanka with the description of five new species. Zootaxa, 1490 (1): 1-63. http://dx.doi.org/10.11646/zootaxa.1490.1.1

Wickramasinghe, L. J. M., Bandara, I. N., Vidanapathirana, D. R., Tennakoon, K. H., Samarakoon, S. R. and Wickramasinghe, N. (2015). Pseudophilautus dilmah, a new species of shrub frog (Amphibia: Anura: Rhacophoridae) from a threatened habitat Loolkandura in Sri Lanka. Journal of Threatened Taxa, 7: 7089-7110. https://doi.org/10.11609/JoTT.o3501.7089-110

Wickramasinghe, L. J. M., Munindradasa, D. A. I. and Fernando, P. (2012a). A new species of Polypedates Tschudi (Amphibia, Anura, Rhacophoridae) from Sri Lanka. Zootaxa, 3498 (1): 63-80. http://dx.doi.org/10.11646/zootaxa.4691.5.6

Wickramasinghe, L. J. M., Vidanapathirana, D. R. and Wickramasinghe, N. (2012b). Back from the dead: the world's rarest toad Adenomus kandianus rediscovered in Sri Lanka. Zootaxa, 3347 (1): 63-68. http://dx.doi.org/10.11646/zootaxa.3347.1.3

Wickramasinghe, L. J. M., Vidanapathirana, D. R., Ariyarathne, S., Rajeev, G., Chanaka, A., Pastorini, J., Chathuranga, G. and Wickramasinghe, N. (2013b). Lost and found: One of the world's most elusive amphibian Pseudophilautus stellatus (Kelaart, 1853) rediscovered. Zootaxa, 3620 (1): 112-128. http://dx.doi.org/10.11646/zootaxa.3620.1.5

Wickramasinghe, L. J. M., Vidanapathirana, D. R., Rajeev, G. and Wickramasinghe, N. (2013c). Rediscovery of Pseudophilautus hypomelas (Günther, 1876) (Amphibia: Anura: Rhacophoridae) from the Peak Wilderness, Sri Lanka, a species thought to be extinct! Journal of Threatened Taxa, 5: 5181-5193. http://dx.doi.org/10.11609/JoTT.o3547.518193

Wickramasinghe, L. J. M., Vidanapathirana, D. R., Rajeev, M. D. G., Ariyarathne, S. C., Chanaka, A. W. A., Priyantha, L. L. D., Bandara, I. N. and Wickramasinghe, N. (2013a). Eight new species of Pseudophilautus (Amphibia, Anura, Rhacophoridae) from Sripada World Heritage Site (Peak Wilderness), a local amphibian hotspot in Sri Lanka. Journal of Threatened Taxa, 5: 3789-3920. https://doi.org/10.11609/JoTT.o3099.3789-920

Wijayathilaka, N., Garg, S., Senevirathne, G., Karunarathna, N. and Biju, S. D., Meegaskumbura, M. (2016). A new species of Microhyla (Anura: Microhylidae) from Sri Lanka: an integrative taxonomic approach. Zootaxa, 4066 (3): 331-342. http://dx.doi.org/10.11646/zootaxa.4420.2.1

Xie, F., Lau, M. W. N., Stuart, S. N., Chanson, J. S., Cox, N. A. and Fischman, D. L. (2007). Conservation needs of amphibians in China: A review. Science in China Series C, 50: 265. http://doi.org/10.1007/s11427-007-0021-5 
Appendix 1: Species checklist of Sri Lankan amphibians (102 species), excluding the extinct species (Native species*; Exotic \#; and + indicates present/ included).

\begin{tabular}{|c|c|c|c|c|c|c|c|}
\hline Species & : & 焉 & 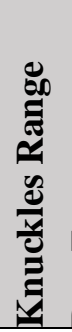 & 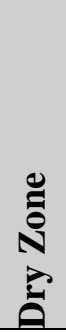 & 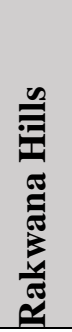 & 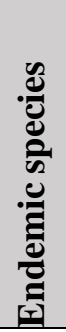 & 造 \\
\hline $\begin{array}{l}\text { Adenomus kandianus (Günther, 1872) } \\
\text { Adenomus kelaartii (Günther, 1858) } \\
\text { Duttaphrynus kotagamai (Fernando and Dayawansa, 1994) } \\
\text { o. Duttaphrynus melanostictus (Schneider, 1799)* } \\
=\text { Duttaphrynus noellerti (Manamendra-Arachchi and Pethiyagoda, 1998) } \\
\text { Duttaphrynus scaber (Schneider, 1799)* } \\
\text { Duttaphrynus stomaticus (Lütken, 1862)\# }\end{array}$ & $\begin{array}{l}+ \\
+ \\
+ \\
+ \\
+ \\
+\end{array}$ & $\begin{array}{l}+ \\
+ \\
+ \\
+\end{array}$ & + & + & + & $\begin{array}{l}+ \\
+ \\
+\end{array}$ & $\begin{array}{l}+ \\
+ \\
+\end{array}$ \\
\hline 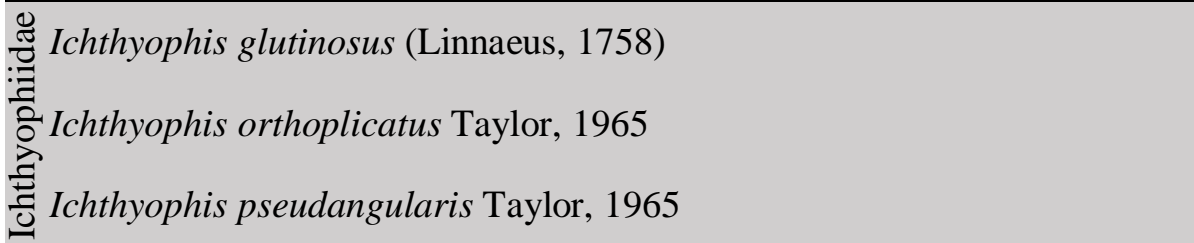 & + & $\begin{array}{l}+ \\
+ \\
+\end{array}$ & + & & + & $\begin{array}{l}+ \\
+\end{array}$ & + \\
\hline $\begin{array}{l}\text { Microhyla karunaratnei Fernando and Siriwardhane, } 1996 \\
\text { Microhyla ornata (Dumeril and Bibron, 1841)* } \\
\text { Microhyla mihintalei Wijayathilaka, Garg, Senevirathne, Karunarathna, } \\
\text { Biju, and Meegaskumbura, } 2016 \\
\text { Microhyla zeylanica Parker and Osman Hill, } 1948 \\
\text {. } \text { Uperodon nagaoi (Manamendra-Arachchi and Pethiyagoda, 2001) } \\
\text { Uperodon obscurus (Günther, 1864) } \\
\text { Uperodon palmatus (Parker, 1934) } \\
\text { Manamendra-Arachchi, Meegaskumbura, and Biju, 2018 } \\
\text { Uperodon systomus (Schneider, 1799)* } \\
\text { Uperodon taprobanicus (Parker, 1934)* }\end{array}$ & + & $\begin{array}{l}+ \\
+ \\
+\end{array}$ & + & $\begin{array}{l}+ \\
+\end{array}$ & + & $\begin{array}{l}+ \\
+ \\
+ \\
+\end{array}$ & $\begin{array}{l}+ \\
+ \\
+ \\
+\end{array}$ \\
\hline 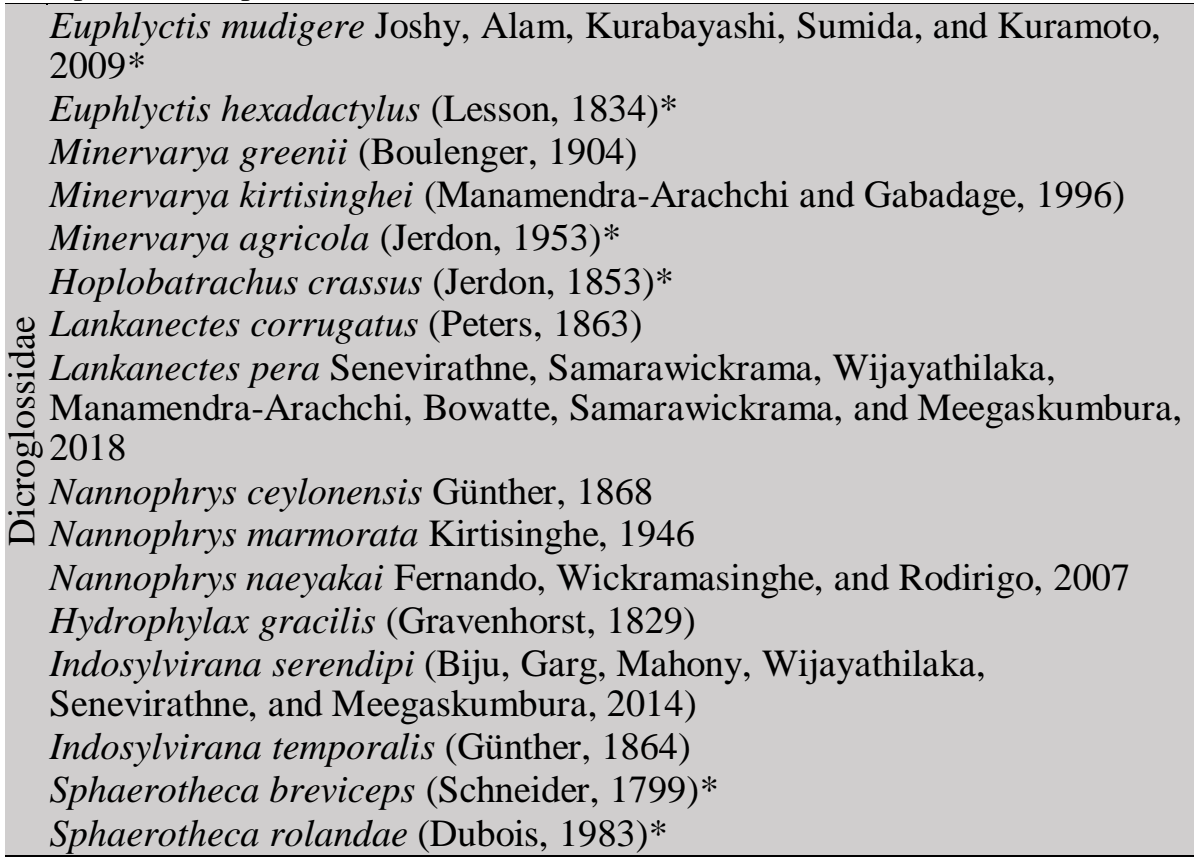 & $\begin{array}{l}+ \\
+ \\
+ \\
+\end{array}$ & $\begin{array}{l}+ \\
+ \\
+ \\
+ \\
+\end{array}$ & $\begin{array}{l}+ \\
+\end{array}$ & $\begin{array}{l}+ \\
+\end{array}$ & $\begin{array}{l}+ \\
+\end{array}$ & $\begin{array}{l}+ \\
+ \\
+ \\
+\end{array}$ & $\begin{array}{l}+ \\
+ \\
+\end{array}$ \\
\hline
\end{tabular}




\section{Appendix 1. (Continued)}

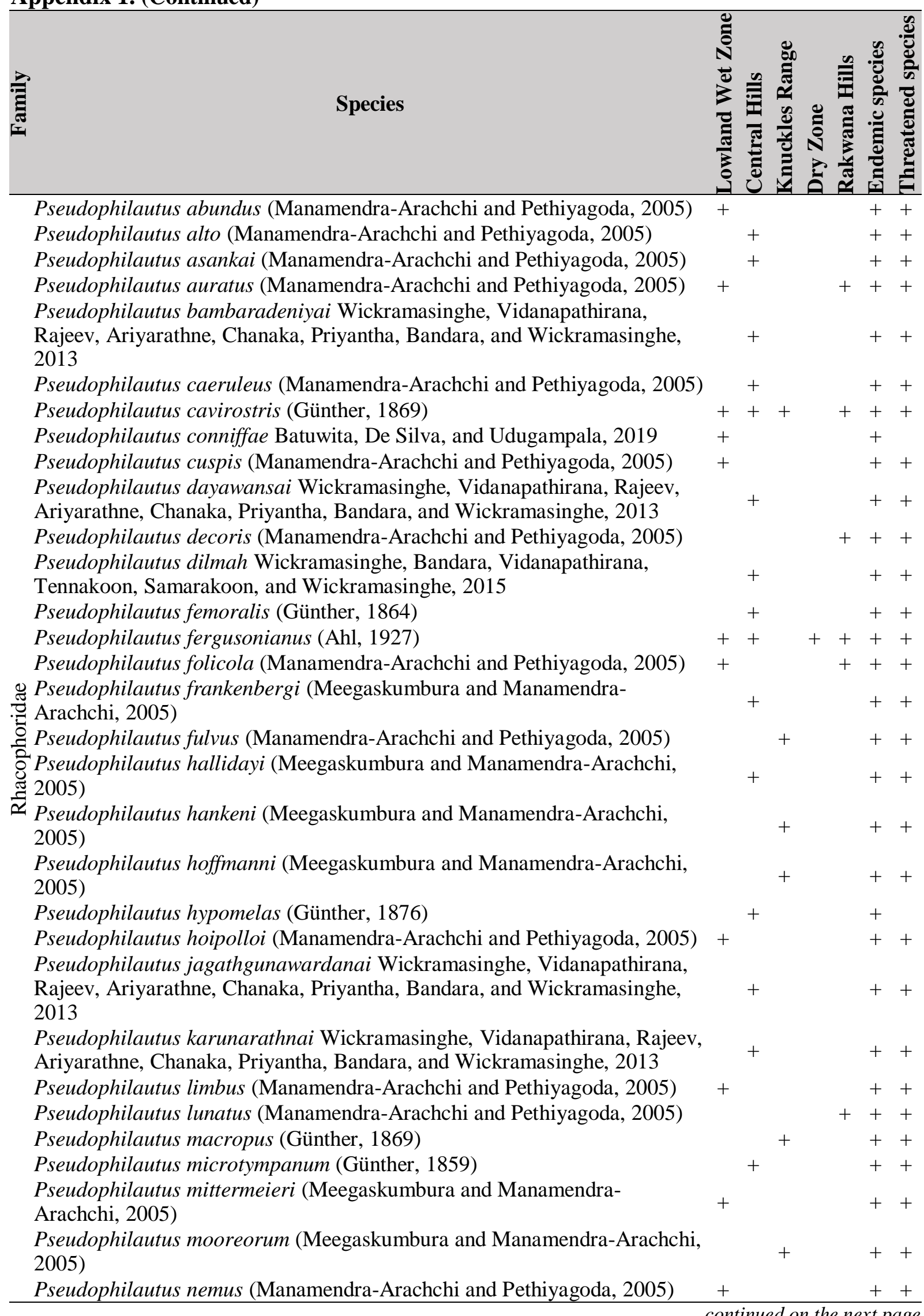


Pseudophilautus newtonjayawardanei Wickramasinghe, Vidanapathirana, Rajeev, Ariyarathne, Chanaka, Priyantha, Bandara, and Wickramasinghe, 2013

Pseudophilautus ocularis (Manamendra-Arachchi and Pethiyagoda, 2005)

Pseudophilautus papillosus (Manamendra-Arachchi and Pethiyagoda, 2005)

Pseudophilautus pleurotaenia (Boulenger, 1904)

Pseudophilautus poppiae (Meegaskumbura and Manamendra-Arachchi, 2005)

Pseudophilautus popularis (Manamendra-Arachchi and Pethiyagoda, 2005) + +

Pseudophilautus procax (Manamendra-Arachchi and Pethiyagoda, 2005)

Pseudophilautus puranappu Wickramasinghe, Vidanapathirana, Rajeev,

Ariyarathne, Chanaka, Priyantha, Bandara, and Wickramasinghe, 2013

Pseudophilautus regius (Manamendra-Arachchi and Pethiyagoda, 2005)

Pseudophilautus reticulatus (Günther, 1864)

Pseudophilautus rus (Manamendra-Arachchi and Pethiyagoda, 2005)

Pseudophilautus samarakoon Wickramasinghe, Vidanapathirana, Rajeev,

Ariyarathne, Chanaka, Priyantha, Bandara, and Wickramasinghe, 2013

Pseudophilautus sarasinorum (Müller, 1887)

Pseudophilautus schmarda (Kelaart, 1854)

Pseudophilautus schneideri Meegaskumbura and Manamendra-Arachchi, 2011

If Pseudophilautus semiruber (Annandale, 1913)

Pseudophilautus silus (Manamendra-Arachchi and Pethiyagoda, 2005)

Pseudophilautus silvaticus (Manamendra-Arachchi and Pethiyagoda, 2005) +

Pseudophilautus simba (Manamendra-Arachchi and Pethiyagoda, 2005)

I Pseudophilautus singu (Meegaskumbura, Manamendra-Arachchi and

Pethiyagoda, 2009)

Pseudophilautus sirilwijesundarai Wickramasinghe, Vidanapathirana,

Rajeev, Ariyarathne, Chanaka, Priyantha, Bandara, and Wickramasinghe, 2013

Pseudophilautus sordidus (Manamendra-Arachchi and Pethiyagoda, 2005)

Pseudophilautus steineri (Meegaskumbura and Manamendra-Arachchi, 2005)

Pseudophilautus stellatus (Kelaart, 1853)

Pseudophilautus stictomerus (Günther, 1876)

Pseudophilautus stuarti (Meegaskumbura and Manamendra-Arachchi, 2005)

Pseudophilautus tanu (Meegaskumbura, Manamendra-Arachchi and Pethiyagoda, 2009)

Pseudophilautus viridis (Manamendra-Arachchi and Pethiyagoda, 2005)

Pseudophilautus zorro (Manamendra-Arachchi and Pethiyagoda, 2005)

Polypedates cruciger (Blyth, 1852)

Polypedates maculatus (Gray, 1834)*

Polypedates ranwellai Wickramasinghe, Munindradasa and Fernando, 2012

Taruga eques (Günther, 1858)

Taruga fastigo (Manamendra-Arachchi and Pethiyagoda, 2001)

Taruga longinasus (Ahl, 1931) 
Appendix 2: Rhacophoridae species distribution according to the elevational gradient (+ indicates present).

\begin{tabular}{|c|c|c|c|c|c|c|c|c|}
\hline \multirow[b]{2}{*}{ Species } & \multicolumn{3}{|c|}{ Low elevations } & \multicolumn{3}{|c|}{ Mid-elevations } & \multicolumn{2}{|c|}{ High elevations } \\
\hline & 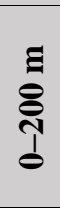 & 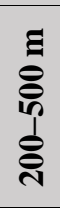 & 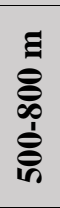 & 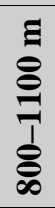 & 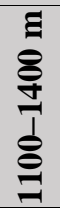 & 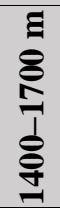 & 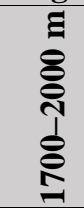 & 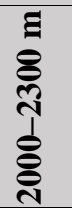 \\
\hline Pseudophilautus abundus & + & & & & & & & \\
\hline Pseudophilautus alto & & & + & + & + & + & + & + \\
\hline Pseudophilautus asankai & & & + & + & + & & & \\
\hline Pseudophilautus auratus & & + & & & & & & \\
\hline Pseudophilautus bambaradeniyai & & & & & & & + & \\
\hline Pseudophilautus caeruleus & & & & + & + & & & \\
\hline Pseudophilautus cavirostris & + & + & + & + & & & & \\
\hline Pseudophilautus conniffae & + & & & & & & & \\
\hline Pseudophilautus cuspis & & + & & & & & & \\
\hline Pseudophilautus dayawansai & & & & & & & + & \\
\hline Pseudophilautus decoris & & & & + & & & & \\
\hline Pseudophilautus dilmah & & & & & & + & & \\
\hline Pseudophilautus femoralis & & & + & & & + & + & \\
\hline Pseudophilautus fergusonianus & & + & + & & & & & \\
\hline Pseudophilautus folicola & + & + & + & + & & & & \\
\hline Pseudophilautus frankenbergi & & & & & & & + & + \\
\hline Pseudophilautus fulvus & & + & + & + & + & & & \\
\hline Pseudophilautus hallidayi & & & + & + & + & & & \\
\hline Pseudophilautus hankeni & & & & & + & + & & \\
\hline Pseudophilautus hoffmanni & & & & + & & & & \\
\hline Pseudophilautus hypomelas & & & + & + & + & & & \\
\hline Pseudophilautus hoipolloi & + & + & + & & & & & \\
\hline Pseudophilautus jagathgunawardanai & & & & & & & + & \\
\hline Pseudophilautus karunarathnai & & & & & & & + & \\
\hline Pseudophilautus limbus & & + & & & & & & \\
\hline Pseudophilautus lunatus & & & & & + & & & \\
\hline Pseudophilautus macropus & & & + & & & & & \\
\hline Pseudophilautus microtympanum & & & & & & + & + & + \\
\hline Pseudophilautus mittermeieri & + & & & & & & & \\
\hline Pseudophilautus mooreorum & & & & & & + & & \\
\hline Pseudophilautus nemus & & + & + & & & & & \\
\hline Pseudophilautus newtonjayawardanei & & & & & & & + & \\
\hline Pseudophilautus ocularis & & & & & + & & & \\
\hline Pseudophilautus papillosus & & & & & + & & & \\
\hline Pseudophilautus pleurotaenia & & & + & & & & & \\
\hline Pseudophilautus poppiae & & & & & + & & & \\
\hline Pseudophilautus popularis & + & + & + & + & & & & \\
\hline Pseudophilautus procax & & & + & & & & & \\
\hline Pseudophilautus puranappu & & & & & & & + & \\
\hline Pseudophilautus regius & + & & & & & & & \\
\hline Pseudophilautus reticulatus & + & + & + & + & & & & \\
\hline Pseudophilautus rus & & & + & & & & & \\
\hline Pseudophilautus samarakoon & & & & & & & + & \\
\hline
\end{tabular}


Appendix 2. (Continued)

\begin{tabular}{|c|c|c|c|c|c|c|c|c|}
\hline \multirow[b]{2}{*}{ Species } & \multicolumn{3}{|c|}{ Low elevations } & \multicolumn{3}{|c|}{ Mid-elevations } & \multicolumn{2}{|c|}{ High elevations } \\
\hline & 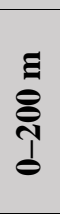 & 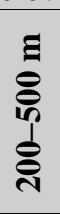 & 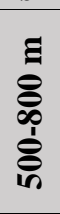 & 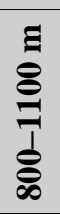 & 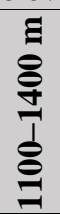 & 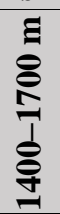 & 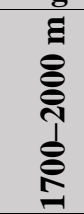 & 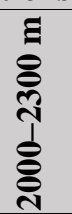 \\
\hline Pseudophilautus sarasinorum & & & + & & + & & & \\
\hline Pseudophilautus schmarda & & & & + & + & + & + & + \\
\hline Pseudophilautus schneideri & + & & & & & & & \\
\hline Pseudophilautus semiruber & & & & & & & + & \\
\hline Pseudophilautus silus & & & & & & + & & \\
\hline Pseudophilautus silvaticus & & & + & + & + & & & \\
\hline Pseudophilautus simba & & & & & + & & & \\
\hline Pseudophilautus singu & + & + & + & + & & & & \\
\hline Pseudophilautus sirilwijesundarai & & & & & & & + & \\
\hline Pseudophilautus sordidus & + & + & + & + & & & & \\
\hline Pseudophilautus steineri & & & & & + & & & \\
\hline Pseudophilautus stellatus & & & & & & + & & \\
\hline Pseudophilautus stictomerus & + & + & + & + & & & & \\
\hline Pseudophilautus stuarti & & & & & + & & & \\
\hline Pseudophilautus tanu & + & & & & & & & \\
\hline Pseudophilautus viridis & & & & & & + & + & \\
\hline Pseudophilautus zorro & & & + & & & & & \\
\hline Polypedates cruciger & + & & + & & & + & & \\
\hline Polypedates maculatus & + & + & & & & & & \\
\hline Polypedates ranwellai & + & & & & & & & \\
\hline Taruga eques & & & + & & & & + & + \\
\hline Taruga fastigo & & & & & & + & & \\
\hline Taruga longinasus & + & + & + & & & & & \\
\hline
\end{tabular}

